\title{
II. Viyana Kuşatması'ndan Sonra Fransız Gravürlerinde Osmanlı Tasvirleri
}

\section{Depictions of the Ottomans in the French Engravings After the Second Siege of Vienna}

\author{
Emine Kırıkcı*
}

Öz

Osmanlı’nın Avrupa'da karşıt bir varlık ve kimlik olarak algılanışı birçok araştırmacı tarafından farklı açılardan değerlendirilmiştir. Bibliothèque National de France'da bulunan Michel Hennin: Estampes Relatives à l'Histoire de France adlı koleksiyona ait 1686-1689 yılları için Paris'te üretilen yedi adet gravürlü almanak / yıllık çalışmanın birincil kaynaklarını oluşturmaktadır. Bu gravürler, II. Viyana Kuşatması'ndan sonra yaşanan savaşları konu edinmektedir ve Avrupa'nın Osmanlı karşısındaki zaferini Roma ve Hristiyan öğelerinden oluşan görsel bir dille anlatır. Makalede her bir gravür ikonografiye dikkat çekilerek betimlenmektedir. Nitekim bu öğelerin ne oldukları ve ne anlama geldikleri açıklandıktan sonra Osmanlıların Avrupalılarca nasıl algılandıklarını incelemek ve Roma ve Hristiyan sembollerinin ve ikonografisinin savaş yıllarında "düşmanı" tasvir etmek için yeniden güncel olana uyumlanmış şekilde anlamlandırılışını ve kullanımını görmek mümkün olacaktır. Gravürlerde kullanılan ikonografi ve sembollerin gösterdiği gibi Osmanlılarla yapılan savaşlara dinî bir tarih anlayışına ve bu anlayışın yarattığı beklentilere göre bir rol verilmiştir.

\section{Anahtar Kelimeler}

Osmanlı imajı, Fransız gravürleri, Roma ve Hristiyan sembolleri, Roma ve Hristiyan ikonografisi, 17. yüzyıl

\begin{abstract}
The European perception of the Ottomans, as an opposite entity and identity, is a topic that has been studied by many scholars and from several perspectives. The present paper investigates this issue too. The seven almanacs with engravings of the collection Michel Hennin: Estampes Relatives à l'Histoire de France found at the Bibliothèque National de France constitute the primary sources that are examined here. These engravings were created in Paris for the years 1686-1689. They are illustrations of the wars that followed the Second Siege of Vienna, and depict the European victory over the Ottomans, with a visual vocabulary which consists of Roman and Christian components. Each engraving is described in detail with an emphasis on the iconography in this study. By explaining what their iconographic components are, and what they mean, it will be possible to analyze the European perception of the Ottomans, and see how the Roman and Christian symbols and iconography were re-loaded and utilized while depicting "the enemy" during the years of war. The employment of such iconography will also show that the wars with the Ottomans were given a place in the historical understanding and expectations that the symbolism which these engravings use.
\end{abstract}

\section{Keywords}

Ottoman image, French engravings, Roman and Christian symbols, Roman and Christian iconography, 17th century

* Sorumlu Yazar: Emine Kırıkcı (Dr. Öğr. Üyesi), Sivas Cumhuriyet Üniversitesi, Mimarlık Güzel Sanatlar ve Tasarım Fakültesi, Mimarlık Bölümü, Sivas, Türkiye. E-posta: ekirikci@cumhuriyet.edu.tr ORCID: 0000-0002-9608-1014

Atıf: Kirikci, Emine. “II. Viyana Kuşatması'ndan Sonra Fransız Gravürlerinde Osmanlı Tasvirleri.” Art-Sanat, 13 (2020): 261-291. https://doi.org/10.26650/artsanat.2020.13.0011 


\section{Extended Summary}

The European perception of the Ottomans, as an opposite entity and identity, is a topic that has been studied by many scholars and from several perspectives. The present paper investigates this issue too. The seven almanacs with engravings of the collection Michel Hennin: Estampes Relatives à l'Histoire de France found at the Bibliothèque National de France constitute the primary sources that are examined here. These engravings were created in Paris for the years 1686-1689. They are illustrations of the wars that followed the Second Siege of Vienna, and depict the European victory over the Ottomans with a visual vocabulary which consists of Roman and Christian components. These almanacs with engravings were created and published with the permission and will of the French King Louis XIV. Therefore, they reflect the employment of the image of the Turk in a political context at a time when the King was being criticized for not joining forces with the Holy League against the Ottomans. The iconography of these engravings can be regarded as a compensation for the absence of the French King in this alliance.

Each engraving is described in detail with an emphasis on the iconography in this study. By explaining what their iconographic components are, and what they mean, it will be possible to analyze the European perception of the Ottomans, and see how the Roman and Christian symbols and iconography were re-loaded and utilized while depicting "the enemy" during the years of war. The employment of such iconography also shows that the wars with the Ottomans were given a place in the historical understanding and expectations which can be found in the symbolism these engravings use.

The conflicts between the European powers with each other, as well as the conflicts between the different churches and confessions would lead, from time to time, to the emergence and/or presence of some perceptions of the Ottomans under a comparatively more positive light. However, the Ottomans were never thoroughly perceived as an "equal" by the Europeans. The difference of religion played a great role in shaping the perceptions and approaching "the other". So, obviously, the vocabulary and the argumentation used to support and keep these images alive reflected the European, Roman and Christian perceptions and interpretations of the world. During the times of conflict and war, the Ottoman image as "the opposite" and "the ultimate enemy" would, of course, become even more highlighted and amplified with regard to the negative and inimical features. The Second Siege of Vienna and the wars that followed it constituted such a period. The victories over the Ottomans inspired not only the German-speaking lands to create works that rather demonized the Ottomans, but they inspired almost the entire European continent. So, many European "nations" saw the Ottomans as a mutual enemy and a force against which they were to ally their forces, usually in the name of religion. The French engravings examined here were produced in this context. So, it should be underlined that with the production and circulation of 
these works, Louis XIV aimed at creating and advocating an image of himself as a supporter of the Holy League. Moreover, they created memories and shaped how these wars, at the end of the seventeenth century, were to be remembered. But they did not create "new" stories. Instead, they interpreted these wars, the European victories and the Ottoman defeats, through "old" and "established" narratives which were employed in the Roman and Christian iconographic vocabulary.

Among the iconographic components in the compositions of these engravings, significant Christian figures and symbols, Evangelist symbols and Roman imperial insignias are found. The role of the "good" and "righteous" is ascribed to the forces of the Holy League via their depiction as being supported by the Christian figures and religious symbols, and/ or carrying and wearing the Roman insignia. The personifications of the European forces and the portrayals of the European rulers and military men occupy the place of the victorious. Their victory is also interpreted and represented in Christian religious terms. The divine and heavenly help and assistance are highlighted as guiding the "righteous". The Ottomans occupy the place of the defeated. Their defeat is also interpreted and represented in Christian religious terms. The role of the "bad" and defeated is ascribed to the Ottomans and along with them to their religion, as the Muslim religious symbols prominently accompany the Ottoman soldiers and are depicted in the same position as them. The French engravings studied here do not, therefore, offer "new" narratives and images necessarily different, for example, from their contemporary Austrian counterparts, discussions of which can be found in earlier studies. However, from an iconographical and iconological point of view, they constitute truly good examples to study the early modern employment of the image of the Turk after the Second Siege of Vienna. 


\section{Giriş}

Osmanlı İmparatorluğu'nun ve Türklerin, Avrupalılar için genelde kendilerinin karşıtı bir kimliği temsil ettiği bilinen bir gerçektir. Bu karşıtlığın temeli sıkça dinî farklılığa dayandırılıp Avrupa Hristiyan dünya yorumu, dinî terimler ve sıfatlarla dillendirilmiştir. Yine Avrupa içinde yaşanan mezhepsel ayrılıklar, münakaşa ve savaşlar, Osmanlı'nın siyasi ve askeri bir ortak olarak düşünülebilmesini mümkün kılmış ancak "eşit" görülmesi için yeterli bir sebep oluşturmamıştır. Bu karşıt olma algısı Viyana kuşatmaları esnasında ve sonrasında keskinleşmiş ve yeniden ifade bulmuştur. Özellikle 15. ve 17. yüzyıl arasında Avrupa dillerinde üretilen eserlerde Osmanlılar, Türkler ve Müslümanlar çoğu zaman birbirinden ayrı düşünülmemiştir. Bu tanımlar, özellikle Hristiyan vurgusu yapılan Avrupa kimliği karşısında aynı kimliği ifade için kullanıldığından ${ }^{1}$ bu yazıda da "Osmanlı/Türk/Müslüman" tasvirinden bir arada bahsedilecektir.

Özellikle 17. yüzyılın ikinci yarısında Avrupa'da Osmanlı İmparatorluğu'nun sonunun yaklaşmış olduğuna dair yüksek bir beklenti oluşmuştur. Hatta Türklerin Hristiyanlığı kabul edeceği kehanetleri, örneğin Katolik Kilisesi'nin Kalvinistleri durdurma yönündeki dilek ve öngörüleri gibi bu dönemde yaygınca kaleme alınmıştır. Ayrıca 1529 I. Viyana Kuşatması'nın aksine 1683 II. Viyana Kuşatması yalnızca Almanca konuşulan coğrafi ve kültürel bir alanda değil, neredeyse tüm Avrupa'da yazılı ve resimli eserlerle belgelenmiştir. Avrupa'da konuşulan neredeyse her dilde II. Viyana Kuşatması'na dair birincil kaynak, basılmış şiir, tiyatro oyunu, rahiplerin kiliselerde verdikleri vaaz, kuşatma altındaki Viyana şehir planı, kişi resim ve amblem türleri başta olmak üzere çok çeşitli malzemelerden oluşur. ${ }^{2}$ Modern tarih ve sanat tarihi çalışmaları da konuyu pek çok yönden incelemiştir. ${ }^{3} 1571$ İnebahtı Savaşı üzerine

1 Bkz. Palmira Brummett, "Turks and Christians: The Iconography of Possession in the Depiction of the Ottoman-Venetian-Habsburg Frontiers 1550-1689," The Religions of the Book: Christian Perceptions 1400-1660, ed. Matthew Dimmock ve Amdrew Hadfield (New York: Palgrave Macmillan, 2008), 111-114, 120; Heather Madar, "Dürer's Depictions of the Ottoman Turks: A Case of Early Modern Orientalism?," The Turk and Islam in the Western Eye 1450-1750: Visual Imagery Before Orientalism, ed. James G. Harper. Second Edition (Farnham: Ashgate, 2013), 178.

2 Bkz. Andrei Pippidi, Visions of the Ottoman World in Renaissance Europe (Londra: Hurst, 2012); Günsel Renda, “Avrupa ve Osmanlı: Sanatta Etkileşim," Osmanlı Uygarlığı, ed. Halil İnalcık ve Günsel Renda (Ankara: Kültür ve Turizm Bakanlığı, 2004), 2:1096-1097, 1102; Walter Sturminger, Bibliographie und Ikonographie der Türkenbelagerungen Wiens 1529 und 1683 (Köln: Böhlau, 1955); Lale Babaoğlu Balkış, "16. - 18. Yüzyıllarda Avusturya Sanatında Türkler" (Doktora tezi, İstanbul Üniversitesi, 1994), 42, 52, 54-55.

3 Bkz. Palmira Brummett, "Turks and Christians: The Iconography of Possession in the Depiction of the Ottoman-Venetian-Habsburg Frontiers 1550-1689,"; Maximilian Grothaus, "Zum Türkenbild in der Adels- und Volkskultur der Habsburgmonarchie 1650-1800," Das Osmanische Reich und Europa 1683-1789: Konflikt, Entspannung und Austausch, ed. Gernot Heiss, Grete Klingenstein (Münih: Oldenbourg, 1983), 63-88; Rhoads Murphey, Ottoman Warfare 1500-1700 (Londra: UCL Press, 1999); Christoph K. Neumann ve Petr Štepánek, "Ottoman-Habsburg Relations in the 17th Century," Image of the Turks in the 17th Century Europe, 12 July-9 October 2005 Exhibiton Catalogue (İstanbul: Sakıp Sabancı Müzesi, 2005), 18-35; Kenneth M. Setton, Venice, Austria, and the Turks in the Seventeenth Century (Philadelphia: American Philosophical Society, 1991); Mustafa Soykut, Image of the "Turk" in Italy: A History of the "Other" in Early Modern Europe 1453-1683 (Berlin: K. Schwarz, 2001); Mustafa Soykut, Papallk ve Venedik Belgelerinde Avrupa'nin Birliği ve Osmanlı Devleti 1453-1683 (İstanbul: İstanbul Bilgi Üniversitesi Yayınları, 2007). 
yapılan çalışmalarda da Avrupa'da Türk algısı ve imajı konu edinilmiştir. İncelenen gravürler için İnebahtı Savaşı'nı betimleyen resimlerin ilham kaynağı olduğu söylenebilir çünkü karşılaştırılabilecek benzer ikonografik motif ve kompozisyonlar oldukça fazladır. Aşağıda da bahsedilecek olan apokaliptik eskatolojik bakış açısının bu savaşın algılanışını da etkilemesi bu durumda önemli bir etkendir. Ancak örneğin Türkleri genelde sembolize etmek için kullanılan ejderha, incelenen gravürlerde hiç kullanılmamıştır; Osmanlılar / Türkler bir devlet kişileştirmesi ya da hükümdar ile kompozisyonda bulunmasa da deforme edilmiş insan figürüyle de gösterilmemiştir. Genelde Osmanlı askerleri esir hâlde dahi giyinik resmedilmiştir. Türk safına korkaklık, cesaretsizlik, ümitsizlik, kötülük, insafsızlık ve vahşilik gibi olumsuz vasıfların kişileştirmelerinin ya da alegorilerinin dâhil edilmediğini görürüz. Fransız gravür sanatçının ya da sanatçılarının tasavvurundaki düşman "iman/din" temelinde farklı ve “yanlış”tır: formunda bir gariplik, doğaüstülük, canavarlık yoktur. ${ }^{4}$

Bu çalışmada 1683 Viyana Kuşatması'nı takip eden yıllarda Paris'te kral XIV. Louis'nin isteği ve izniyle basılan yedi adet gravürlü almanak ikonografik yönden incelenecek ve yorumlanacaktır. Bu gravürler, Fransa'nın tarihine yönelik gravür çalışmalarından oluşan Bibliothèque nationale de France-Michel Hennin Koleksiyonu'na aittir. Gravürlerde Fransız sanatçının ya da sanatçıların, Avrupa'nın Hristiyan kimliğine 17. yüzyıl Avrupa sanatının en sevdiği malzemesi denilebilecek alegorik figürlerin de kompozisyona dâhil edilmesiyle nasıl vurgu yaptı̆̆ gösterilecektir. Diğer yandan bu illüstrasyonlarda Osmanlı askerinin İslam dinini temsil eder şekildeki tasviri, Hristiyan Avrupa devletleri kişileştirmelerine ve/veya tasvirlerine boyun eğmiş, mağlup olmuş ve korku içinde gösterilmiştir. İncelenecek olan gravürlü almanaklar o dönemde Fransa'nın kendisini, ${ }^{5}$ Avrupa'yı ve Osmanlı'yı nasıl algıladığını göstermektedir. Fransa için bu resimlerin üretilmesi XIV. Louis'nin Katolik Kilisesi'nin koruyucusu olduğunun altını çizmek ve Osmanlılarla dostane bir ilişkisi olduğu eleştirilerine cevap vermek için önemlidir. ${ }^{6}$ Bu eleştiriler, kral 1684 'te Kutsal İttifak'a katılmayı reddedince Fransa ve Avrupa çapında oldukça yoğunlaşmıştır. ${ }^{7}$ Aslında XIV. Louis'nin

4 İnebahtı Savaşı ile ilgili görseller için bkz. Naz Defne Kut, "Iconography of a Catholic Victory: The Battle of Lepanto in Italian Painting" (Yüksek Lisans tezi, Koç Üniversitesi, 2018); Benjamin Paul, "And the Moon Has Started Bleed: Apocalypticism and Religions Reform in Venetian Art at the Time of the Battle of Lepanto," The Turk and Islam in the Western Eye 1450-1750: Visual Imagery Before Orientalism, ed. James G. Harper. Second Edition (Farnham: Ashgate, 2013), 67-94; Christina Strunck, "The Barbarous and the Noble Enemy: Pictorial Representations of the Battle of Lepanto," The Turk and Islam in the Western Eye 1450-1750: Visual Imagery Before Orientlism, ed. James G. Harper. Second Edition (Farnham: Ashgate, 2013), 217-240. Daha kapsamlı bir çalışma için bkz. Géraud Poumarede, Haçlı Seferine Son Çağrl: Yeniçă̆ Avrupası 'nda Osmanlı İmgesi, çev. İsmet Birkan (İstanbul: İletişim, 2010).

5 Burada incelenen gravürlerle çağdaş ve aynı matbaalarda basılan ancak ikonografi ve ikonoloji olarak farklılık gösteren bazı diğer gravürler için bkz. Meredith Martin ve Gillian Weiss, "Turks on Display during the Reign of Louis XIV," L'Esprit Créateur 53/4 (2013), 98-112.

6 Nitekim ikonografik ve ikonolojik olarak karşılaştırılabilecek eserler Versailles saray duvarlarında, resmi madalyonlarda ve diğer almanaklarda bulunabilir. Martin ve Weiss, "Turks on Display during the Reign of Louis XIV," 98, 102, 103, 105-106. Ayrıca bkz. Babaoğlu Balkış, “16. - 18. Yüzyıllarda Avusturya Sanatında Türkler,” 18.

7 Martin ve Weiss, "Turks on Display during the Reign of Louis XIV," 103, 106. 
bu politikası, Fransa'nın I. François'dan beri izlediği politikadan çok farklı değildir. Yürütülen güçler dengesi politikası gereği, Fransız hükümdarları Osmanlılarla siyasi, ticari ve askeri ilişkileri sürdürürken diğer Avrupa ülkelerine ve halka yönelik olan propaganda ve imaj çalışmalarında Osmanlıların ortak düşman olduğu vurgusunu yapiyorlardı. Bu durum, kralın otoritesinin Avrupa devletlerince ve halklarınca sarsılmaması, aksine güçlenmesi bakımından önemliydi. ${ }^{8}$ XIV. Louis'nin II. Viyana Kuşatması ve takip eden savaşlarda Kutsal İttifak'a askeri bir yardımda bulunmamasına ve Osmanlılarla ticari ilişkilerini sürdürmesine rağmen dağıttığı madalyonlar ve yaptırdığg sanat eserleri onun Kutsal İttifak'ı desteklediği, Kutsal İttifak'ın yanında olduğu ve zaferlerini kutladığı imajını oluşturma çabası olarak değerlendirilebilir. Aynı zaman$\mathrm{da}$, almanakları süslemeleri nedeniyle hatıra yaratma ve hatırlatma amacını taşıyan bu gravürler, Osmanlı'nın 17. yüzyıl sonunda Viyana kuşatmasını takip eden yıllarda Avrupa kıtasındaki mağlubiyetlerinin Avrupa için nasıl hatırlanması gereken zaferler olarak düşünüldüğünü göstermektedir.

\section{Savaşlar ve "Ezeli Düşmanlık"}

13. yüzyıldan itibaren Kutsal Roma-Germen İmparatorluğu'nun en önemli kısmını oluşturan Habsburgların politik güç ve prestij yönünden zirvede olduğu 16. ve 17. yüzyıllarda sınırları genişleyen Avusturya, 16. yüzyılda Osmanlıların Avrupa'daki topraklarına komşu durumundadır. Bu coğrafi komşuluk ve savaş hâli, diplomatik, siyasi, askeri ve kültürel ilişkilere zemin hazırlamıștır. Avusturya'nın egemenliğinde olan Macar toprakları için Osmanlı İmparatorluğu'na her yıl vergi vermesini şart koyan İstanbul Antlaşması Kanuni döneminde düzenlenmiştir. Pek çok politik ve askeri sebepten ve resmi olarak 1547 y1lından itibaren ödenmesi șart koşulan verginin verilmeyeceğinin bildirmesinden dolayı 1593 yılında Osmanlılar ve Habsburglar arasında savaş başlamış ve böylece 1606 yılına kadar sürecek savaşlar dönemine girilmiştir. Bu savaşlarda pek çok yer Avusturyalılarla Osmanlılar arasında el değiştirmiştir. Bilindiği üzere, 1606 yılında imzalanan Zitvatorok Antlaşması ile Avusturya hükümdarı artık Osmanlı hükümdarına eş unvana sahip kabul edilmiștir. ${ }^{10}$ Osmanlı tehdidine karşı Hristiyanlığın savunucusu olduğu iddiasıyla hükümranlığının propagandasını yapan II. Rudolf'ün ${ }^{11}$ saray ressamı Hans von Aachen'in 1604 civarında Türk Savaşları üzerine yaptığı alegorik yağlı boya resimler, yedi adet gravürlü almanaktaki kimi

8 Halil İnalcık, "Siyaset, Ticaret, Kültür Etkileşimi," Osmanlı Uygarlı̆̆g, ed. Halil İnalcık ve Günsel Renda (Ankara: Kültür ve Turizm Bakanlığı, 2004), 2: 1052-1053.

9 Martin ve Weiss, "Turks on Display during the Reign of Louis XIV," 104

10 Bkz. Georg Wagner, "Otuz Yıl Savaşları Döneminde Osmanlı ve Avusturya İmparatorluklarının Politikası," Osmanlı Araştırmalarl 2 (1981), 147-166; Harald Heppner, "Der Lange Türkenkrieg (1593-1606)-Ein Wendepunkt im habsburgisch-osmanischen Gegensatz," Osmanlı Araştırmaları 2 (1981), 133-146.

11 Eckhard Leuschner, "Donau-Toporaphie und -Allegorie in der Türkenkriegspropaganda Zwischen Rudolf II. (1552-1612) und Leopold I. (1640-1705)," Barocke Kunst und Kultur im Donauraum: Beiträge zum Internationalen Wissenschaftskongress, 9.-13. April 2013 in Passau und Linz, ed. Karl Möseneder, Michael Thimann ve Adolf Hofstetter (Petersberg: Imhof, 2014), 1:117. 
detaylarla karşılaştırılabilir. ${ }^{12}$ Resim ve gravürlerde arka plandaki eş zamanlı savaş sahneleri, esir, yaralı ve ölü Osmanlı askerleri, bazı sembol ve kişileştirmeler böyle bir yaklaşımı mümkün kılabilir fakat farklı anlam yüklemelerine dikkat edilmelidir. Çünkü ressam, Hristiyan öğeleri ve anlatımı ana unsurlar olarak belirlememiştir, kompozisyonları ağırlıkla Romalı/pagan unsurlar ve mitolojik/epik anlatımlarla tasarlamıştır. Önemli bir diğer fark ise iki taraftan birinin aslında karşı konulamaz bir üstünlükle resmedilmemiş oluşudur. Resmedilen savaşlar önceden geleceği belli olan bir sonun habercisi değildir, daha ziyade Gök'ün desteğiyle kazanılan savaşın ve kazandıkları müddetçe Gök’ten gelen tebrikin resmedilişidir. Göksel şahitlik ve müdahale yine söz konusudur: Savaşın kararı Gök’te mitolojik tanrılar tarafından verilmiştir ve yerdeki sahneler, Gök’te bulutlar arasındaki küçük sahnelerde verilen sembolik eylemlerin âdeta bir yansımasıdır.

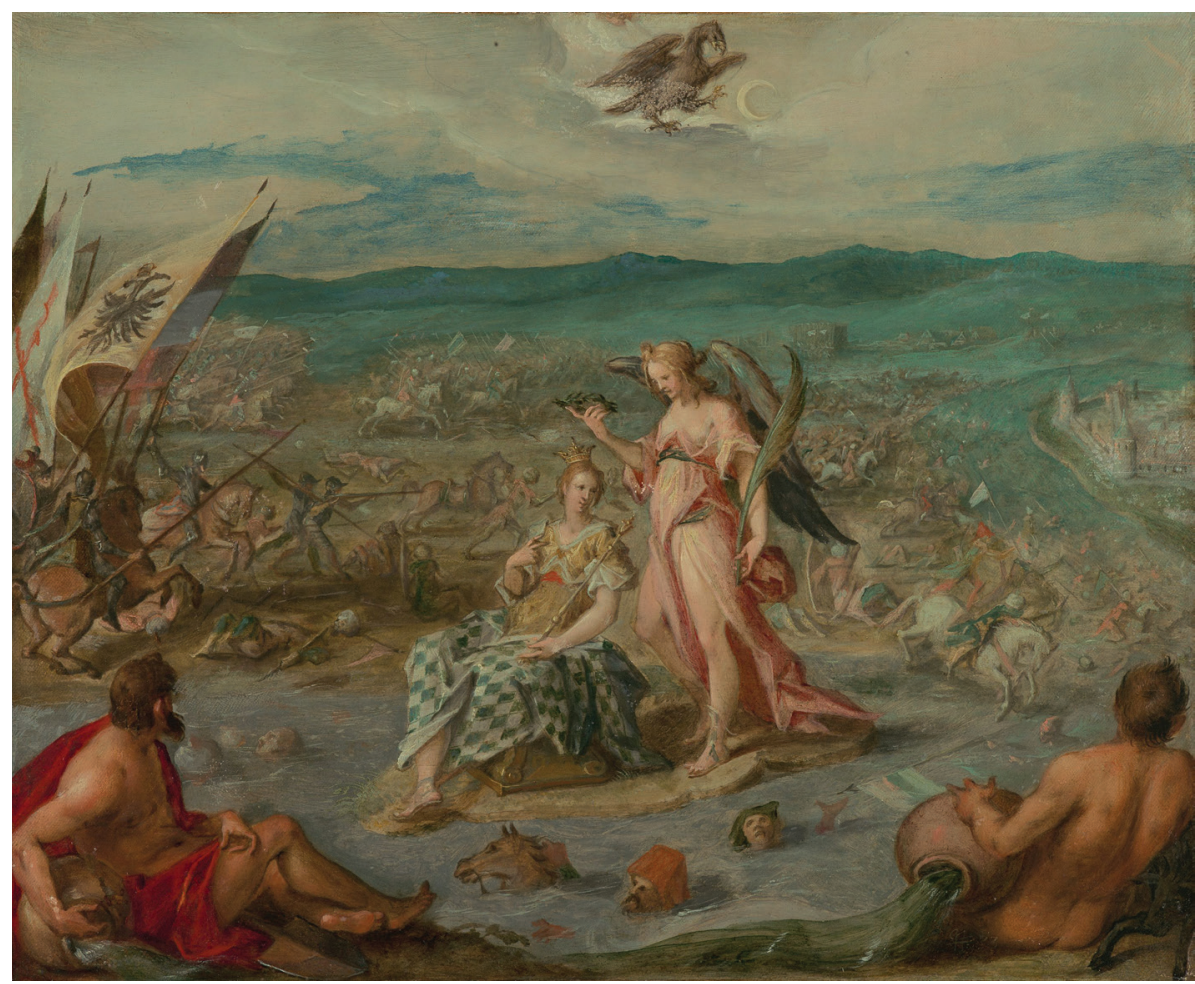

G. 1. Hans von Aachen, Schlacht bei Sisseck (1593 Kulpa Bozgunu). Merkezde Viktorya ya da Zafer kişileştirmesi, Hırvatistan ya da Steiermark kişileştirmesine taç takmaktadır. (C) KHMMuseumsverband. Kunsthistorisches Museum, Viyana. www.khm.at/de/object/3c59dc048e/ erişim 1 Aralık 2019.

12 Hans von Aachen, Fünf Allegorien auf den Langen Türkenkrieg Kaiser Rudolfs, II. Kunsthistorisches Museum, Viyana. Örnek için bkz. (G. 1). Uzun süren savaşlar dönemini konu edinişi, eş zamanlı savaş sahnelerini arka planda verişi, alegorik öğelerin ön planda oluşu ve ilahi yardımın vurgulanışı nedeniyle de bu resimler incelenen gravürler ile karşılaştırılabilir. Alegorileri detaylı inceleyen bir çalışma için bkz. Mirka Campbell Fetté, "Saving Political Face: The Structure of Power in Hans von Aachen's Allegories on the Long Turkish War" (Yüksek Lisans tezi, The University of Texas at Austin, 2011). 
Yüzyılın sonundaysa güç dengeleri Osmanlı İmparatorluğu aleyhine gelişmiş ve Avrupa'da Türk korkusu sönmüştür. ${ }^{13}$ Avrupa'daki Osmanlı korkusu Osmanlıların 14. yüzyılda Balkanları fethetmesi sonucu oluşmuş ve takip eden yüzyıllarda Osmanlı'nın genişlemesi ve askerî üstünlüğünü çok defalar kanıtlaması ile beraber bu korku sıkça dillendirilmiştir. Osmanlı ordularının 1463'te Osmanlı-Venedik savaşı sırasında Avusturya topraklarına girmesi, çok uzun sürecek olan Osmanl1-Avusturya mücadelesine yol açmakla kalmayıp aynı zamanda Hristiyan âlemi tarafından Osmanlı'nın ciddi ve büyük bir tehdit unsuru olarak algılanmasına neden olmuştur. Özellikle I. Viyana Kuşatması'yla doruk noktasına varan Türk korkusu, Türklerin "Der Erbfeind" ya da "ezeli düşman" olarak tanımlanmasına yol açmış ve Osmanlılara karşı gelişen, Osmanlılarda somut ifadesini bulan ve şekillenen bir düşman ortaya çıkarmıştır. Bu bağlamda Viyana kuşatmaları "ezeli düşman” algısının sembolü hâline gelmiş ve tüm Avrupa'nın Hristiyanlık için kenetlenmesine aracı olmuştur. Viyana kuşatmaları, aynı zamanda başta Macaristan olmak üzere diğer Balkan kaleleri, ovaları ve şehirleri için de savaş ve mücadeleyi beraberinde getirmiştir. ${ }^{14}$ Bilhassa Viyana'yı koruma ve Macar topraklarını Osmanlı'dan geri alma gayesi tüm Avrupa'yı birleştiren bir motivasyon görevi görmüştür. ${ }^{15}$ Nitekim Papa, bütün Hristiyanları mukaddes harbe çağırmıştır. Osmanlı-Habsburg savaşı, böylece Avrupa gözünde bir HristiyanMüslüman savaşı hâlini almıştır. Osmanlıların Avrupalılarla savaşları 1699 Karlofça Antlaşması'na kadar devam etmiştir.

1683 II. Viyana Kuşatması'ndan sonra güç dengelerinin Osmanlı aleyhine dönmesi ve gücünü kaybetmiş Türk imajı sanat ve kültür ortamını etkilemiştir. Bu dönemde Türk imajı Avrupa'da birçok sanat alanında fazlaca rağbet görmüş, zaman zaman da Türk modası olarak kıyafetlere yansımıştır. "Korkunç ve barbar baş düşman" tasvirinin yanında, özellikle yüksek kültürde ve aristokrasi mensupları arasında gelişen etnografik merak ile de Türk tasvirleri daha seküler ve kısmen daha objektif olarak karşımıza çıkabilmektedir. ${ }^{16}$

13 Brummett, "Turks and Christians: The Iconography of Possession in the Depiction of the Ottoman-VenetianHabsburg Frontiers 1550-1689", 111. Sürecin detaylı analizi için bkz. Soykut, Image of the "Turk" in Italy: A History of the "Other" in Early Modern Europe 1453-1683.

14 Babaoğlu Balkıș, "16.-18. Yüzyıllarda Avusturya Sanatında Türkler,” 1, 7, 10-14, 18-20; Madar, "Dürer’s Depictions of the Ottoman Turks: A Case of Early Modern Orientalism?," 156-157; Y1lmaz Öztuna, Osmanl Devleti Tarihi (İstanbul: Ötüken Neşriyat, 2004), 2: 296; Wagner, "Otuz Yıl Savaşları Döneminde Osmanlı ve Avusturya İmparatorluklarının Politikası," 147.

15 Öztuna, Osmanlı Devleti Tarihi, 339.

16 "Turquerie" üzerine bkz. Nebahat Avcığlu, Turquerie and the Politics of Representation 1728-1876 (Londra: Routledge, 2016); Johanna Fassl, "Punchinello Meets the Turk: Giambattista Tiepolo's Chorus of Oriental Spectators and the Transformation of Cultural Otherness," The Turk and Islam in the Western Eye 1450-1750: Visual Imagery Before Orientalism, ed. James G. Harper (Farnham: Ashgate, 2013), 95-125; Maximilian Grothaus, "Eine Untersteirische Turquerie, Ihre Graphischen Vorbilder und Ihre Kulturhistorische Bedeutung, " Institut für Österreichische Geschichtsforschung 95/3-4 (1987), 271-295; Grothaus, "Zum Türkenbild in der Adels- und Volkskultur der Habsburgmonarchie 1650-1800"; İnalc1k, "Siyaset, Ticaret, Kültür Etkileşimi," 1057, 1062-1065; Renda, "Avrupa ve Osmanlı: Sanatta Etkileşim," 2: 1107-1110; Haydn Williams, Turquerie: An Eighteenth-Century European Fantasy (New York: Thames \& Hudson, 2014). 
Avusturya önleri ve Balkanlar'da gerçekleşen savaşlar tüm Avrupa'da yankı bulmuş ve ilgiyle takip edilmiştir. İnceleyeceğimiz 1686-1689 yılları için Paris’te üretilen almanakları süsleyen gravürler Türklerin nasıl hatırlanmak istediği üzerine resmedildiğini gösterir.

\section{Gravürlerin İkonografik ve İkonolojik Olarak İncelenmesi}

Fransa' da her y1l sonuna doğru Paris ve diğer büyük şehirlerdeki matbaalarda büyük boyutlarda binlerce almanak basılırdı. Bunlar ait oldukları seneye ait önemli politik olayları vurgularlar ve gelen yılın takvimini gösterirlerdi. Hem caddelerde hem de matbaalarda oldukça ucuza satılan almanaklar şehir halkının toplandı̆̆ ve mekânlarda duvarlara asılırdı. Genelde orta sınıfa ve şehirde çalışan nüfusa hitap ederlerdi. Almanak üretiminin on kat arttığı XIV. Louis döneminde almanaklar önemli propaganda araçlarını teşkil etmekteydi. ${ }^{17}$ Almanaklarda gösterilecek olan gravürleri resmi görevliler belirlerdi. Dolayısıyla, gravürlü almanaklar, kralın askeri, diplomatik ve dinî alanlarda oluşturmak istediği imajı yaymanın önemli unsurlarındandı. ${ }^{18}$

İnceleyeceğimiz gravürler Osmanlı'ya karşı kazanılan zaferler ve bu zaferlerin Hristiyanlık ve Avrupa için ne anlama geldiğini gösteren tasvirler ile bezenmişlerdir. Avrupalıların Osmanlı İmparatorluğu'nu galip etmesi Avrupalılarca her şeyden önce Hristiyanlığın bir zaferi, “doğru” inancın kanıtı olarak algılanmıştır. İncelenen gravürlerin ikonografisi de yoğunlukla kiliselerde ve dinî içerikli resimli el yazmalarında İsa'nın ve Hristiyanlığın zaferini anlatan tasvirlerin hem doğrudan figürlerini ve simgelerini içermekte hem de bunların karakteristik özelliklerinin dönemin devletleri ve hükümdarlarıyla bağdaştırılmasından oluşmaktadır.

Gravürlere geçmeden konuyla ilgili olarak 15. yüzyıl sonundan bir Dürer resmindeki Türk tasvirine değinmek yerinde olacaktır. ${ }^{19}$ Evanjelist Yuhanna'nın Roma imparatoru Domitianus tarafından kaynar bir yağ kazanında yakılmak istenişi ve aniden bastıran yağmurun buna engel oluşu, hayatının Karş1-Reformasyon dönemine kadar Avrupa'da ilgi görüp tasvir edilmiş sahnelerindendir. Dürer'in ksilografi tekniğiyle meydana getirdiği on beş tabloluk Apokalips eseri de bu sahne ile başlar (G. 2). ${ }^{20}$

17 Martin ve Weiss, "Turks on Display during the Reign of Louis XIV," 106.

18 Martin ve Weiss, "Turks on Display during the Reign of Louis XIV," 106-107.

19 Dürer'in eserlerinde Türk figürünün kullanımı için bkz. Lale Babaoğlu Balkış, "15. Yüzyıl Sonu, 16. Yüzyıl Başında Avrupa'daki Türk İmajının Albrecht Dürer'in Eserlerine Yansıması,, Gelenek, Kimlik, Bireșim: Kültürel Kesişmeler ve Sanat: Günsel Renda ya Armağan, ed. Zeynep Yasa Yaman ve Serpil Bağc1 (Ankara: Hacettepe Üniversitesi, 2011), 61-68; Madar, "Dürer's Depictions of the Ottoman Turks: A Case of Early Modern Orientalism?"; Guido Messling, "The Northern View: Albrecht Dürer and the Ottomans," The Sultan's World. The Ottoman Orient in Renaissance Art. Catalogue of the Exhibition at the Centre for Fine Arts, Brussels, 27 February- 31 May 2015, The National Museum in Krakow, 26 June- 27 September 2015, ed. Robert Born, Michal Dziewulski, Guido Messling (Ostfildern: Hatje Cantz, 2015), 53-56; Larry Silver, "East is East: Images of the Turkish Nemesis in the Habsburg World," The Turk and Islam in the Western Eye 1450-1750: Visual Imagery Before Orientalism, ed. James G. Harper (Farnham: Ashgate, 2013), 185-196.

20 Bkz. Albrecht Dürer, "Die Ölmarter des Evangelisten Johannes,” 1497-1498. 
Resimde Roma şehrinin önünde toplanan halk, merakla kazan içindeki Yuhanna'y1 izlemektedir. Yuhanna'yı ne üzerine dökülen kaynar yağ yakabilmekte ne de yanan ateş kazandaki yağı alevlendirebilmektedir. Yuhanna zarar görmemiş hâlde dua etmektedir. Domitianus olarak düşünebileceğimiz, tahtta oturup ayakları çapraz bağ 1 konumda hükmü veren hâkim olarak tasvir edilen erkek figürün ve pagan Roma halkındaki kimi figürlerin kavuk takıyor olması elbette bize dönemin Türk ve Müslüman algısıyla ilgili fikir verebilir. Albrecht Dürer, Hristiyan tarihi ve inancında önemli yer tutan kimselerin karşılaştığı muktedir ancak zalim yöneticiler ile Hristiyanlığı kabul etmeyen ve bu nedenle de cezalandırılacaklarına inanılan pagan milletleri Türk ve/ veya Müslüman kılık kıyafetinde tasvir etmiş̧ir. Sanatçı, Doğulu tasviri için Osmanlı İmparatorluğu ve daha sonraları Memlük Devleti'nden gelen Müslümanları doğrudan model olarak resmedemese de onları Venedik şehrinde görmüş ve model tasvirlerini Venedik’teki sanatçı atölyelerinde -başta Gentile Bellini'ninki olmak üzere- çalışmış ve bunun üzerine göreceli standart sayılabilecek bir Doğulu figürünü oluşturmuştur. Nitekim, eserlerindeki Osmanlı ve/veya Müslüman olarak tanımlanabilecek figürler birbirinden ifadeleri dışında genelde büyük farklılıklar sergilemez ve "milli" bir kimlik tespiti için dönemin okunmasını gerektirir. ${ }^{21}$ Dürer, Apokalips'inde üç sahnede daha Türk figürlerine yer vermiştir. Apokaliptik olayların yaşandığg bu sahnelerde, Türkler, "yanılan, yanlış, sapmış" inançları olan ve bu nedenle kendileri kurtulamadıkları gibi diğerlerinin kurtuluşunu da engelleyen dünyevi ve dinî liderler ve "milletler" yanında gösterilmiştir. ${ }^{22}$ Dürer, dönemindeki edebî, dinî ve politik dili resim sanatına taşıyarak Yuhanna'nın Vahiy Kitabı ikonografilerinde Osmanl1/Türk/Müslüman figürlerine geçmiş, şimdi ve gelecekteki “Antichrist”ler ya da Hristiyanlık ve dolayısıyla Tanrı düşmanlığını simgeleyen dinî/tarihî karakterler olarak yer vermesi yönünden öncü olmuştur. ${ }^{23} \mathrm{Bu}$ algıya göre, Türk ve Müslümanlar, Hristiyanlar için

21 Madar, "Dürer's Depictions of the Ottoman Turks: A Case of Early Modern Orientalism?," 159, 160, 164-16, 176; Messling, "The Northern View: Albrecht Dürer and the Ottomans," 53-54; Türk giysili figürler özellikle Tevrat ve İncil'deki sahneleri betimlemek için kullanılırdı. Bkz. Renda, "Avrupa ve Osmanlı: Sanatta Etkileşim," 1095.

22 Madar, "Dürer's Depictions of the Ottoman Turks: A Case of Early Modern Orientalism?," 164-172.

23 Madar, "Dürer's Depictions of the Ottoman Turks: A Case of Early Modern Orientalism?," 158-159. Yuhanna'nın Vahiy Kitabı yalnızca Türkler üzerinden okunmamıştır; dönemin politik krizleri, iklimi ve dili sembollerin yorumlanmasına ilham vermiştir. Aslında önceleri, 15. yüzyıl civarına kadar, pagan Roma İmparatorluğu ve Romalılar üzerinden yorumlanmıştır. Madar, "Dürer's Depictions of the Ottoman Turks: A Case of Early Modern Orientalism?," 172-176. Özellikle erken dönem Hristiyanlık'ta, Musevilik ve İslam'a Hristiyan dünya tarih algılayışı, yorumu ve beklentisi içinde "sonunda mağlup olacak olan düşman" rolü sıklıkla verilmiştir ve bu durum Hristiyanların gözünde bu dinlerin ve mensuplarının imajını oldukça etkilemiş ve şekillendirmiştir. Matthew Dimmock, "A Human Head to the Neck of a Horse: Hybridity, Monstrosity and Early Christian Conceptions of Muhammad and Islam,"The Religions of the Book: Christian Perceptions 1400-1600, ed. Matthew Dimmock ve Andrew Hadfield (New York: Palgrave Macmillan, 2008), 66-67, 77; İnalcık, "Siyaset, Ticaret, Kültür Etkileşimi," 1075. Yine bahsi geçen dünya görüşü bağlamında, Osmanlılara "geçici" gözü ile bakılmıştır. Palmira Brummett'in Avrupa-Osmanlı sınırlarındaki şehir, bölge ve kalelere ait harita tasvirlerini ve bunların ikonografik öğelerini incelediği makalesi bu görüşü destekler. Brummett, "Turks and Christians: The Iconography of Possession in the Depiction of the Ottoman-Venetian-Habsburg Frontiers 1550-1689," 118, 120-121, 132. Avrupa'da Osmanl1/Türk figürünün Apokaliptik eskatoloji bağlamında kullanılmasından bahseden bir diğer yazı için bkz. Paul, "And the Moon Has Started 
kendi inanç tarihlerinde söz edilen efsanevi ya da tarihî "zalim"lerin içinde bulunulan çağdaki beklentiye karşılık bedenleşmesidir ve dolayısıyla kaynak metinlerde geçmeseler de "imansız (ya da "yanlış/sapkın" inançl1)", "kötü” ve "zalim” figürünü sembolde ve gerçekte "canlandırmak" adına seçilmişlerdir. ${ }^{24}$ Ancak Messling'in de dediği gibi bu çizimler her zaman sadece "zalim”i simgelemez, Dürer'in yabanc1 kültürlere olan ilgisini ve "Doğu" ile dolaylı olarak ya da doğrudan etkileşimde bulunduğu Venedik'te geçen yıllarının etkisinin göstergesidir. ${ }^{25}$

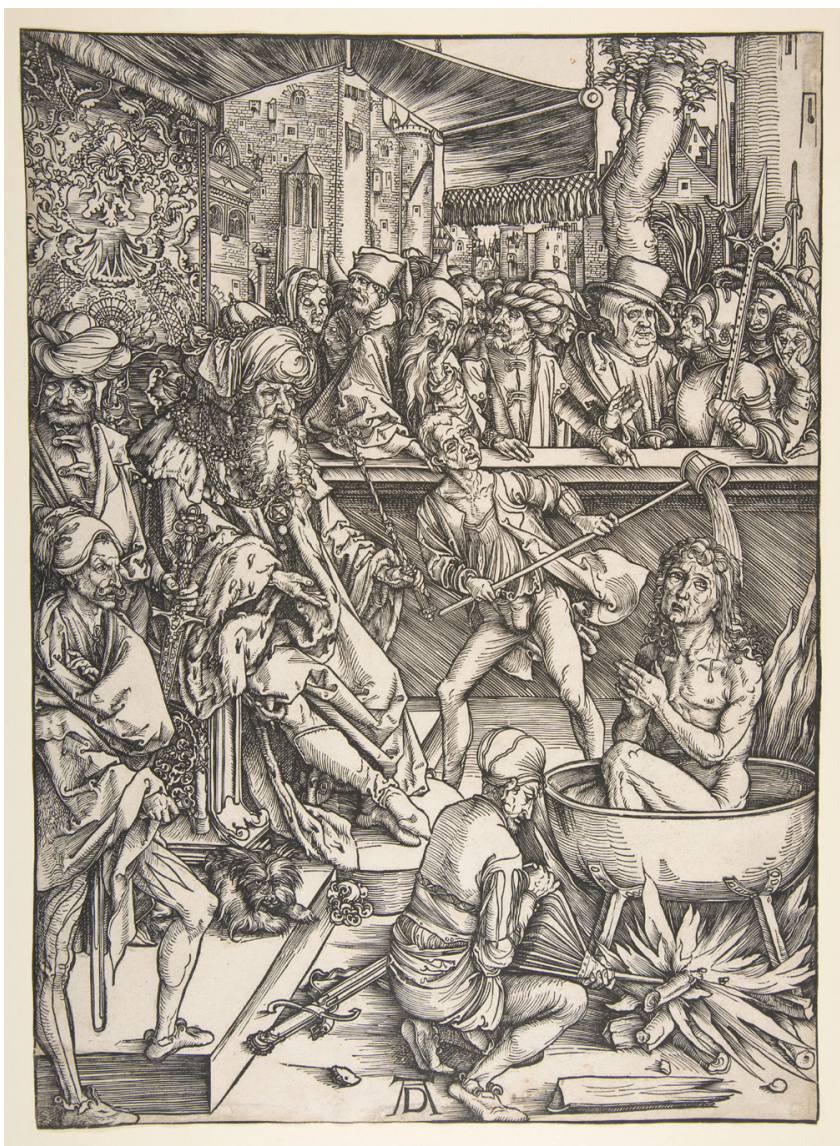

G. 2. Albrecht Dürer, Aziz Yuhanna'nın Şehit Oluşu "The Martyrdom of Saint John from the Apocalypse", erişim 1 Aralık 2019, https://www.metmuseum.org/art/collection/search/387568.

Bleed: Apocalypticism and Religions Reform in Venetian Art at the Time of the Battle of Lepanto." Paul, Hristiyan düşünce tarihinde eskatoloji ve Apokaliptik eskatolojiyi şöyle açıklar: "Within the history of Christian thought, the word eschatology has traditionally referred to the teaching about the last things such as the theological doctrines of heaven, hell, judgment, and life after death. Apocalyptic eschatology, however, concerns visible, objective, and public events (like the Battle of Lepanto) that are considered cosmic in scope and implication. "Paul, "And the Moon Has Started to Bleed," 73.

24 Madar, "Dürer's Depictions of the Ottoman Turks: A Case of Early Modern Orientalism?," 165; Silver, "East is East: Images of the Turkish Nemesis in the Habsburg World," 193-195.

25 Messling, "The Northern View: Albrecht Dürer and the Ottomans," 53. 
Gerçekten de, 15-17. yüzyıllarda filozoflar, din adamları ve yazarlar başta olmak üzere pek çok Avrupalı düşünür, Türkleri kendi milletlerinden önce Hristiyanlık ve İsa düşmanı olarak görmüşlerdir. Dolayısıyla Avrupalıların Türk tehdidini aşmaya çabalarken "yanlış" hatta "yalancı" olarak gördükleri İslamiyeti de Hristiyan dinine boyun eğmiş olarak görmek istedikleri dönemin bir gerçeğidir. ${ }^{26}$ Dürer’in bu eserinden akılda kalması gereken nokta, Türklerin Avrupa'ya üstün geldiği dönemlerde Türk figürünün imparator gibi yüksek makam ve kimlikleri temsil edebilmesidir. İnceleyeceğimiz gravürlerde Avrupa’ya üstünlüğün kaybedilmesinden sonra Türklerin ve Müslümanların, Hristiyan ikonografisinden oluşan tasvirlerine “iyi ve doğru”nun "kötü ve yanlış"1 tamamen mağlup ve mahkûm ettiği dönemin -yani zamanın sonunun- ilham verdiğini görmekteyiz.

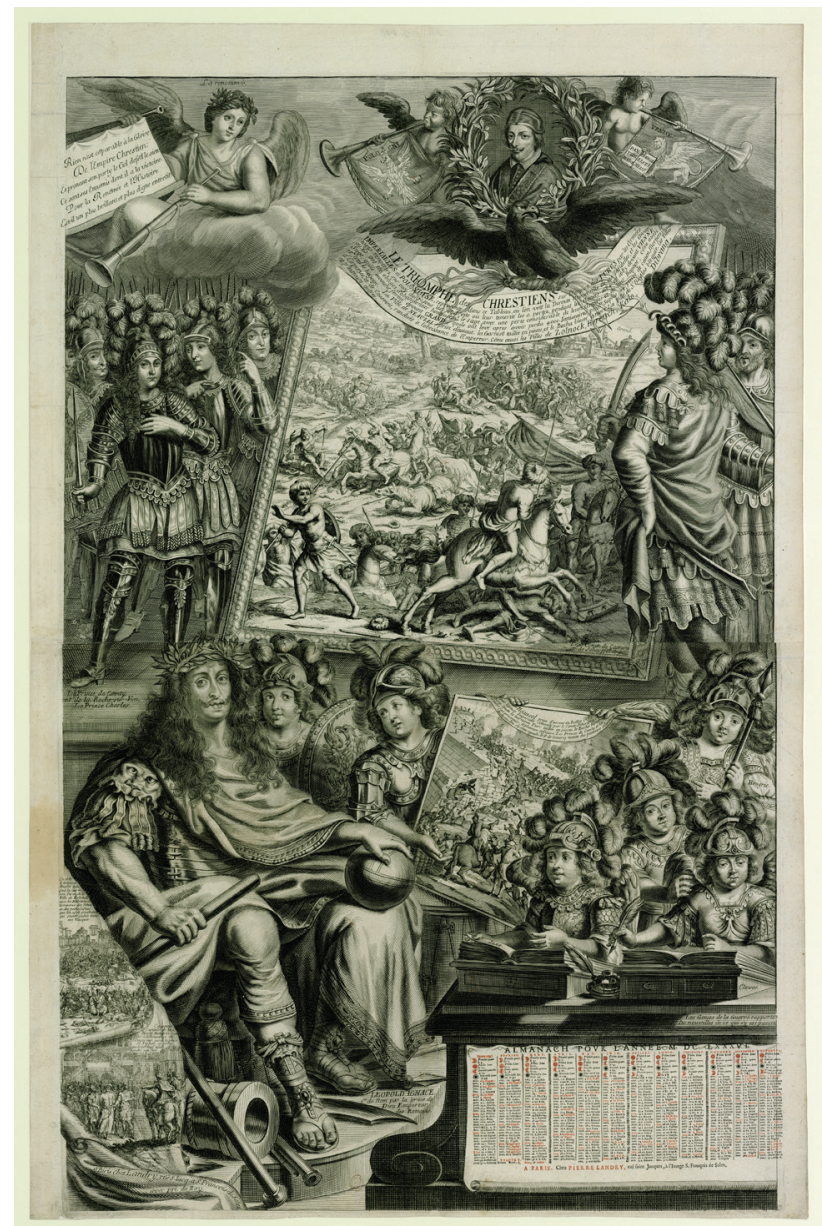

G. 3. Pierre Landry, 1686 Almana $\breve{g} l$ (Kaynak gallica.bnf.fr / BnF)

26 Bu konuda bkz. Pippidi, Visions of the Ottoman World in Renaissance Europe; Sturminger, Bibliographie und Ikonographie der Türkenbelagerungen Wiens 1529 und 1683; 25. dipnotta adı geçen kaynaklarda da bu duruma vurgu yapilır. 
1686 almanağ $1^{27}$ (G. 3) bir nevi başlık mahiyetindeki gökteki iki grubu takip eden iki ana sahneden oluşur. Ana sahnelerin her biri sayfanın yaklaşık yarısını kaplamaktadır. Solda gördüğümüz bir bulutun üzerindeki kanatlı ve başında defne yapraklı çelenk taşıyan figür, yazıyla "La renommée”, yani “ün/şan/şöhret” olarak tanıtılır. Figür, sol elinde bir borazan taşırken, sağ elindeki kumaş üstüne yazılmış metni seyirciye gösterir. Kendisi ise bakışlarını sağdaki gruba çevirmiştir. Taşıdı̆̆ı yazıyla, Hristiyan imparatorluğunun şanının hiçbir şey ile kıyaslanamayacağı, Gök'ün de onları destekleyerek kendine ait olanı koruduğu ve böylece tarihte daha şanlı bir anın olmadığı iddiasında bulunmaktadır. Sağdaki grup dört figürden oluşmaktadır. Onların da etrafı daha az belirgin olsa da yine bulutludur. Merkezde çelenk ile çevrili olarak Papa XI. Innocentius'un portresi yer almaktadır. Portrenin sağında ve solunda birer putto, borazan üfler. Soldakinin borazanına Lehistan arması, sağdakinin borazanına da Venedik'in arması asılmıştır. Çelengin altına kanatlarını açmış ve başını sağa çevirmiş bir kartal yerleştirilmiştir. Kartal pençelerinde eğilip bükülen Türk oklarını tutmaktadır. Bu kompozisyon, Papa'nın Osmanlı'ya karşı Avrupalıları birleştirmedeki rolüne şükran vurgusu yapar. Birinci ana sahnede Alman ve Fransız prens ve komutanlarından bazıları bir tabloyu incelemektedir, diğerleriyse seyirciye bakmaktadır. Tabloda Viyana önlerinde Avrupalı askerlerce bozguna uğratılan Osmanlı askerleri resmedilmiştir. Üstündeki kurdelede Türk Imparatorluğu'na karşı Hristiyanların zaferi yazmakta ve bu zafer İmparatorluk ordularıyla Lehistan ordularına atfedilmektedir. "Infidelles", yani “emin olmayan, inançsız/imansız” diye nitelenen Türklerin mağlubiyeti için "mutlak hezimet” gibi ifadeler kullanılmaktadır. İkinci ana sahnede solda tahtının üzerinde oturan Roma imparatoru kıyafetiyle Leopold Ignaz resmedilmiştir. Yalnızca saçları ve bıyı̆̆ kendi dönemine uygundur. Sol elinde bir küre, sağ elinde de bir asa tutmaktadır ki bunlar imparatorluk nişanlarıdır. Ayaklarının altında Türklere ait olduğunu düşünebileceğimiz savaş malzemeleri görülür. Sağ tarafta, "Genies"28 olarak adlandırılan zırh ve miğferler içinde kanatlı çocuklar yer almaktadır. Altlarındaki açıklamaya göre savaşa dair haberleri yazmaktadırlar. Eski Doğu inanç ve dillerinde cinler ile de karşılaştırılabilecek olan "genius"lar, Roma dininde ömrü boyunca bir kimseyi koruyan ve ona ilham veren ruhlar olarak hayal edilen varlıklardır. Burada her birinin üstünde Osmanlı'ya karşı savaşan Avrupa devletlerinin ismi yazılıdır. Dolayısıyla, aynı zamanda bu ülkelere de eşlik edilen ruhları simgelemektedir. Hem geniusların imparatora gösterdikleri tabloda hem de imparatorun tahtının yanındaki kumaşta Türklerden alınan Macaristan'daki şehirler ve esir düşen Türkler gösterilmektedir. Bu kompozisyonda Macaristan ve Avusturya’da Türklere karşı alınan zaferlerin, katılan tüm Avrupalı güçler için ne kadar mühim, hatta hayati olduğu fikri ifade bulmuştur.

27 Bibliothèque Nationale de France, Recueil. Collection Michel Hennin. Estampes Relatives à l'Histoire de France. Tome 62, Pièce 5476. (Boyutları 87,4 cm x 55,4 cm) (gallica.bnf.fr / BnF)

28 Fransızca "génie" terimi, Latince "genius" teriminden gelir ve bu kelimenin çoğuludur. 


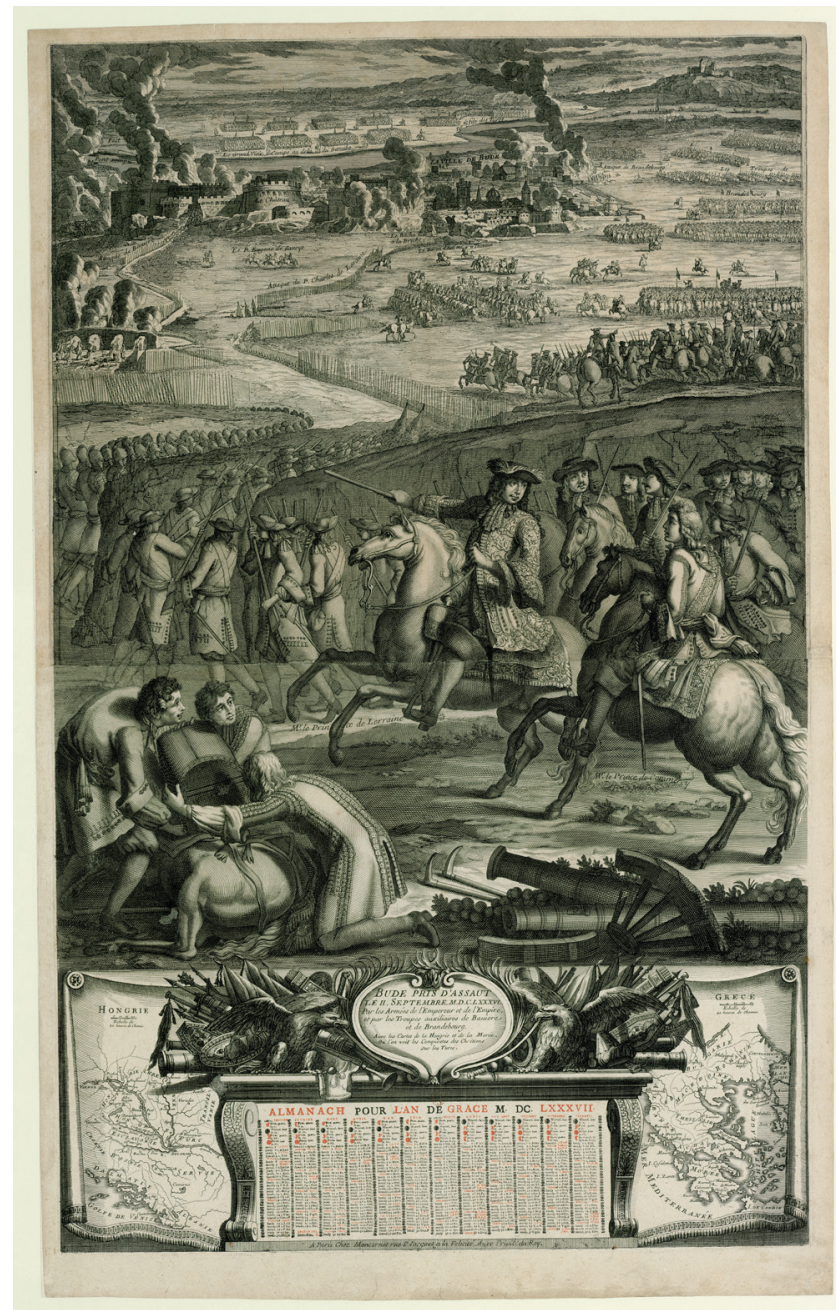

G. 4. Jean Moncornet, 1687 Almanağı (Kaynak gallica.bnf.fr / BnF)

1687 almanağını ${ }^{29}$ (G. 4) yukardan aşağıya incelediğimizde ilkin Peşte kıyılarındaki Türk kampı tasvirini görürüz. Budin ${ }^{30}$ tarafındaysa kale yanmakta ve Bavyera ve Brandenburg güçleriyle Lorraine Dükü Charles ve Savoy Prensi Eugen komutanlığındaki güçler kaleye saldırmaktadır. Resmin merkezinde sağ tarafta at üstünde emir verirken Lorraine Dükü görülür. Sol yanlarındaysa erzaklarını sunan Budin köylüleri görülmektedir. Yüzlerce asker kaleye doğru harekete geçmiştir, çoğunun yalnızca mızrak ve

29 Bibliothèque Nationale de France, Recueil. Collection Michel Hennin. Estampes Relatives à l'Histoire de France. Tome 63, Pièce 5554. (Boyutlar1 89,7 cm x $56 \mathrm{~cm}$ ) (gallica.bnf.fr / BnF)

30 1529'da Osmanlı topraklarına katılan Budin, Brummett'in gösterdiği gibi, Avrupalıların yeniden "Hristiyan toprağı" olmasını ümitle bekledikleri bir şehirdi. Brummett, "Turks and Christians: The Iconography of Possession in the Depiction of the Ottoman-Venetian-Habsburg Frontiers 1550-1689," 120-121. Macaristan coğrafyasının gerçekten de Osmanlı ve Avrupa devletleri arasındaki güç çekişmesinde prestij açısından kilit bir rol oynamış olduğu söylenebilir. İnalcık, “Siyaset, Ticaret, Kültür Etkileşimi,” 1059. 
miğferleri resmedilmiştir. En alt bölümde, sağ ve sol taraftan Macaristan ve Yunanistan haritalarıyla üstten iki zafer kartalının üzeri hilal motifli Osmanlı savaş aletleri önünde sunduğu levha ile çevrelenen takvim yer almaktadır. Kartalların tuttuğu levhada ana başlık olarak Fransızca “Budin taarruzu 2 Eylül 1687” ve altında da katılan güçler ile “Türklere galip gelinen yerler” olarak haritanın açıklaması yazmaktadır.

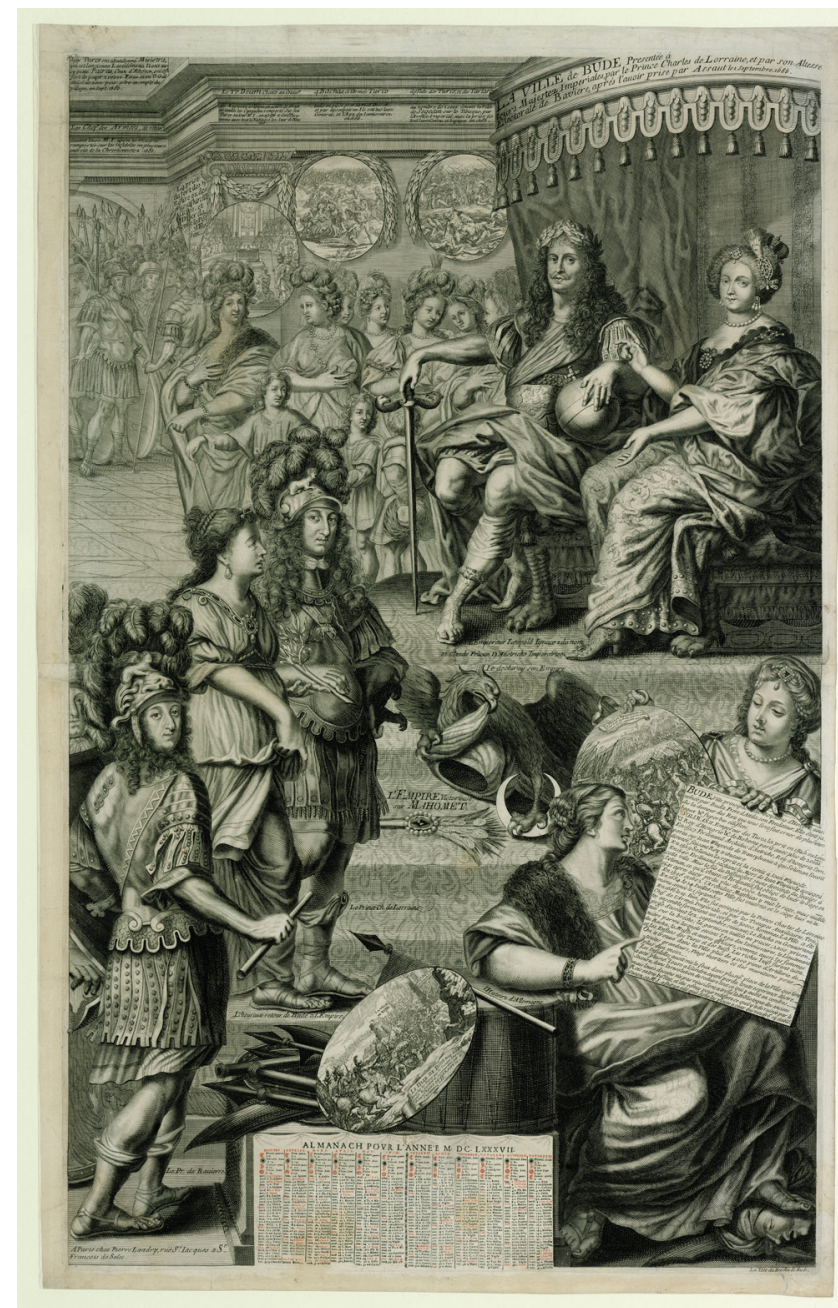

G. 5. Pierre Landry, 1687Almanağg (Kaynak gallica.bnf.fr / BnF)

Bir diğer 1687 tarihli almanak ${ }^{31}$ (G. 5) incelenen almanaklar içinde sembolik ve içerik olarak en dikkat çeken ve en yoğun olanlardan biridir. Dört sahneden oluşan sayfada sağ diyagonal eksen üzerindeki figürler birbiriyle iletişim hâlindedir ve resmin ana konusunu oluşturmaktadır. Nitekim resmin başlı̆̆ı sayabileceğimiz ekseni

31 Bibliothèque Nationale de France, Recueil. Collection Michel Hennin. Estampes Relatives à l'Histoire de France. Tome 63, Pièce 5547. (Boyutları 88,9 cm x 55,6 cm) (gallica.bnf.fr / BnF); Yıl sırasına göre ele aldığımız almanaklar arasında bazı yıllar için iki almanak örneği bulunmaktadır. 
başlatan, imparatorluğu simgeleyen perde ve tahtın üzerinde görülen yazıda "Prens Charles de Lorraine ve yüksek Bavyera Elektörü tarafından Emperyal 1 Eylül 1686 taarruzu ile alınan Budin'in Majestelerine sunuluşu” yazmaktadır. Söz konusu olan majesteleri bilindiği gibi Kutsal Roma İmparatoru Leopold Ignaz'dır. İmparatoriçe, dönem kıyafetleri giymiş olarak resmedilirken, imparator bir Roma imparatoru giysileri içinde gösterilmiştir. Başındaki defne yapraklı çelenk muzaffer oluşunu simgeler. Sol elinde İsa'nın sanat tarihinde "salvator mundi" (dünyanın/âlemin kurtarıcısı) olarak bilinen tasvirinin temel parçası olan haçlı küreyi tutmaktadır. Ancak küre, politik bir açıdan imparatorluğun hâkimiyet alanı olarak da yorumlanabilir. ${ }^{32}$ Sağ elinde tuttuğu çift başlı kartal kabzalı kılıç da yine Roma imparatorluk ikonografisine göre muvaffakiyeti ve dünya hâkimiyetini simgelemektir. İmparator ve imparatoriçe seyirciye bakmakta ve imparatoriçe sağ eliyle işaret ettiği imparatorun başarısına dikkati çekmektedir.

Eksenin sol kısmında Bavyera Prensi, Lorraine Dükü Charles ve arkalarında yalnızca başı görünen erkek bir figür, imparatorun huzuruna çıkan bir kadın figüre eşlik etmektedir. Prensler seyirciye, kadın figür de imparatora bakmaktadır. Antik Roma emperyal kıyafetleri içinde ancak saçları dönemin modasına göre çizilmiş bu figürlerin miğferleriyse antik Yunan tanrı miğferlerinden esinlenmiştir. Böylece antik dönem tanrı tasvirlerini çağrıştırmaktadırlar. Kendisi de Roma kıyafetleriyle tasvir edilen bu kadın figürü, Budin şehrinin kişileştirmesidir. Sol eliyle Lorraine Dükü’nün elini tutmaktadır. Dükün elindeyse bir zeytin dalı görülmektedir. Budin şehrinin kişileştirmesinin altında "Budin'in imparatorluğa mutlu dönüşü” yazmaktadır. Bu grup ve taht arasındaki basamaklar üstünde bir kartal figürü yer almaktadır. Altında "Muhammed'e galip gelen imparatorluk" ve üstünde ise "imparatorluğunu parçalıyor" yazan bu kartalın pençesiyle hilali sıkıca kavradığı ve gagasıyla de sorgucu kopan bir sarığı çözüp parçalamakta olduğu görülür. Kartal figürünün antik Roma ve Hristiyan sanatında, “zafer”i olduğu gibi “iyi”yi de temsil ettiği unutulmamalıdır. En yükseklerde uçup en diplerdeki yılanları yakalayan, Güneş’ten rahatsız olmayan kartal öteden beri 1şı̆̆ 1 simgeleyen sembollerden biridir. Bu yüzden tanrı ve hükümdar tasvirlerinde kartala sıkça rastlanır. Zamanla kartal, İsa'yı simgeleyen sembollerden biri hâline de gelmiştir. Özellikle İsa’nın göğe yükselişi (kartalın uçuşu) ve ölümü yenişi (kartalın yılanı alt etmesi) ile özdeştirilir. Ayrıca, bu benzetmede İsa “dünyanın 1şı̆̆ı” sıfatıyla anılırken, yılan da öteden beri olduğu gibi yine "karanlığın efendisi” rolündedir. ${ }^{33}$ Kartal, Kutsal İttifak'ın sembolü olarak da 1571 İnebahtı Savaşı'na giden süreçte kullanılmıştır. ${ }^{34}$ Tüm bu anlam katmanlarını göz önünde bulundurduğumuzda, almanağın merkezinde

32 Bkz. Uwe Fleckner, Martin Warnke ve Hendrik Ziegler, Handbuch der Politischen Ikonographie, (Münih: C. H. Beck, 2011), 1: 162, 385, 495.

33 Bkz. Heinrich Schmidt ve Margarethe Schmidt, Die Vergessene Bildersprache Christlicher Kunst: Ein Führer zum Verständnis der Tier-, Engel- und Mariensymbolik (Münih: C. H. Beck, 2007), 34-39.

34 Paul, “And the Moon Has Started to Bleed," 76. 
gördüğümüz kartalın bu pozda tamamlayıcı figürünün aslında bir yılan olması beklenmelidir. Dolayısıyla, gaga ve pençesindeki Türk ve Müslüman sembolleri, yani sarık ve hilal, yılanın yerini tutmuştur. Bu figür, Roma ve Hristiyanlığın yukarıda da değindiğimiz "Erbfeind”ının, yani ezeli düşmanının Türk ve Müslümanlar olduğunu söylemektedir.

Gravürün üst bölümünde görülen bordürde Macaristan'da Kutsal İttifak'ın ele geçirdiği yerler ve kazandığı zaferler, Osmanlı ordularının kayıpları ve gördüğü zararlar, bunun üzerine Viyana'da yapılan kutlamalar, kilisede “Te Deum” ilahisinin okunuşu gibi sevinçli hadiseler olarak gördükleri anlar kaydedilmiştir. Altındaki defne yapraklı çelenk ile sarılı daire şeklinde madalyonlarda bu anlar resmedilmiştir. Soldaki askerler ise savaşta başarılı olan askerleri, kadınlar ise kutlama yapan asilleri temsil etmektedir. En altta bulunan takvimin üstünde savaş aletleri, bir davul ve bu davula yaslanmış bulunan elips bir madalyon vardır. Burada Kutsal İttifak’ın Budin üzerine gerçekleştirdiği taarruz resmedilmiştir. Davulun üstüne sağ dirseğini dayayan kadın figürü görülmektedir ve dirseğinin altındaki yazının belirttiği üzere "Almanya tarihi” olarak isimlendirilmiştir. Dolayısıyla, bu kadın, Alman tarihinin kişileştirmesidir. Figürün ismi, pozu ve kıyafetinden yola çıkarak çiziminde mitolojik, tarih yazımı ilham perisi Kleio tasvirlerinin model alındığını söyleyebiliriz. İşaret ettiği metin de küçük bir kronolojik tarih metni tarzındadır. Budin'in tarihini Attila’nın kardeşi tarafından kuruluşuyla başlatan metin, bu şehrin Kanuni Sultan Süleyman'ın fethinden sonra Avrupalılarca geri alınma çabalarına değinir. 1686 yılından daha uzunca bahseder. Kutsal İttifak'ın şehri ele geçirdiğini, rütbeli asker ve yöneticilerin, Türkler gibi Yahudi kadın ve çocukların da esir düştügüünü, zengin Yahudilerin ise öldürüldüğünü yazar. Aynı zamanda çok sayıda ganimet ve savaş malzemesi de ele geçirilmiştir. Bir diğer bilgi de "infidelles” yani “inançsız/imansız” olarak gördükleri Türklerin kurtuluş umudunu kaybettikten sonra şehirde pek çok yeri ateşe verdiğidir. Eski kralların kütüphanesinin kurtulduğunun haberi mutlulukla verilirken, imparatorun kararıyla şehre yerleşmek isteyenlere de izin verildiği bildirilmektedir. Ayrı bir yazıyla kimliği belirtilmeyen, metni ve madalyonu Alman tarihi kişileştirmesine sunan, değerli taşlar takan kadın figürün de Budin şehrinin kişileştirmesi olduğunu düşünebiliriz. Son olarak, her ne kadar sayfanın en alt köşesinde bulunsa da, gözden kaçmaması gereken bir detay da "Alman tarihi”nin sol ayağının altında bulunan sarıklı ve bıyıklı kesik baştır. ${ }^{35}$ Altındaki Fransızca açıklamada başın Budin paşasına ait olduğu bildirilmektedir.

35 Kesik başın Avrupa sanatındaki anlamı için bkz. Diane Apostolos-Cappadona, "Beheading/Decapitation," Encyclopedia of Comparative Iconography: Themes Depicted in Works of Art, ed. Helene E. Roberts (Chicago ve Londra: Fitzroy Dearborn, 1998), 117-124. Genel olarak, savaş söz konusu olduğunda başın ruh, güç, canlılık ve vizyonu simgelediği söylenebilir. Kesik olması durumunda da düşmanın bu özelliklerini kaybettiği ya da artık tehdit oluşturmadığı söylenebilir. “Türk Kafaları” Avusturya'da özellikle II. Viyana Kuşatması'ndan sonra ev damlarına ve çeşme başlarına yerleştirilmiştir. Bu eski gücünü kaybeden korkunç düşman figürlerinin kötülüklere karşı koruyucu olduğuna inanılmıştır. Babaoğlu Balkış, “16. - 18. Yüzyıllarda Avusturya Sanatında Türkler,” 56. 


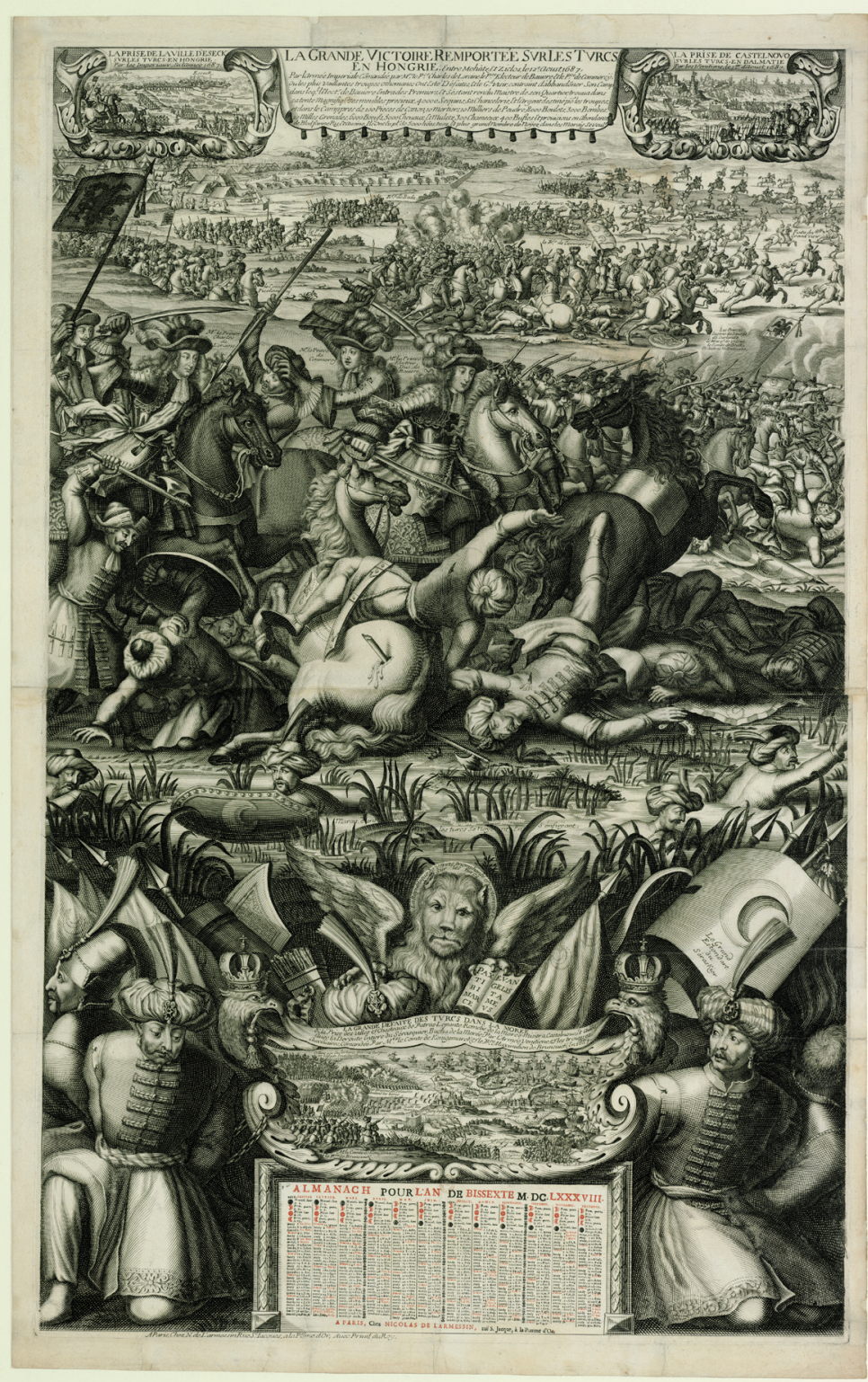

G. 6. Nicolas de Larmessin, 1688 Almanağ (Kaynak gallica.bnf.fr / BnF)

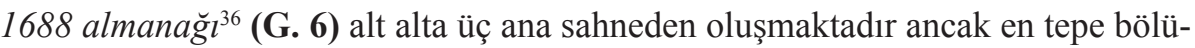
münü yine yazılı bir açıklama ve iki küçük kuşatma tasviri kaplamaktadır. Sağdaki tasvirde Kastelnovo'nun 1 Ağustos 1687'de Venedik kontrolüne geçmesi, solda da Ösek şehrinin yine 1687 yılında imparatorluk ordularınca kazanılması gösterilmiştir.

36 Bibliothèque Nationale de France, Recueil. Collection Michel Hennin. Estampes Relatives à l'Histoire de France. Tome 64, Pièce 5613. (Boyutlar1 94,3 cm x 59,8 cm) (gallica.bnf.fr / BnF). 
İki levha arasındaki yazı "Macaristan'da Türklere karşı kazanılan büyük zafer” başl1ğını taşımaktadır. Söz konusu olan Mohaç bozgunudur. Geride bırakılmak durumunda kalınan Kara Mustafa Paşa'nın meşhur çadırında değerli mobilyalar, 40000 sikke, sanduka, askerler için olan bol miktarda para, çeşitli değerli savaş malzemeleri, sığırlar, develer, katırlar ve benzeri birçok eşya ve malzeme bulunduğu kiminin de yakındaki sazlıktan toplandığı anlatılmaktadır. Takip eden üst ana bölümde iki kısımdan oluşan bir savaş sahnesi vardır. Solda arka planda terk edilmiş hâldeki Osmanlı çadırları, silahları, ağır topları, binek ve büyükbaş hayvanları görülür. Roma-Germen İmparatorluğu ve Hırvat askerlerinin Osmanlı askerlerini kaçmaya zorlayan saldırıları ve savaş sonu galibiyetleri gösterilmiştir. Kimi Osmanlı askerlerinin yerde cansız bedenleri görülürken, hâlâ at üstündekiler canlarını kurtarmak için yaralılarla ya da kayıplarıyla ilgilenemeden hızla kaçmaktadırlar. Sayfanın merkezindeki sahne de yukarıdakinin detay çalışması gibi görülebilir. Osmanlı askerleri, sancakları, silahları yerdedir, Avrupalı askerlerin mızrak ve atlarınca ezilmektedirler. Üstündeki Fransızca nota (...Et plus grand nombre de nö̈ez dans les marais se voult sauver) göre bataklıkta/sazlıkta kaçmaya çalışırken boğulan Türkler resmedilmiştir. Aynı manaya gelen bir notla ( $m a-$ rais, dans leql les turcs se noyent en s'enfü̈ant) sazlık/bataklık da Türklerin kaçmaya çalışırken boğulduğu sazlık/bataklık olarak belirtilmiştir. Altta, takvimi çevreleyen bölümde, sırma kaftanları, sorguçları ve kıyafetlerinden üst düzey asker oldukları anlaşılan, iki sağda iki de solda olmak üzere dört Osmanlı diz çökmüş, elleri arkadan bağlanmış bir şekilde üzüntü ve şaşkınlıkla bakınmaktadırlar. Sağda, hilalli seraskerlik sancağı yazıyla özellikle belirtilmiştir. Yine arka planda hilalli sancaklar yer alır. Askerlerin ortasında ve takvim bölümünün üstünde kartal başları ve üstünde de kanatlı bir aslan tarafından çevrelenmiş bir savaş tasviri yer almaktadır. Üzerlerindeki haç ve küreyle imparatorluk tacı olduğu vurgulanan taçları taşıyan kartallar Kutsal Roma-Germen İmparatorluğu'nu temsil ederken, kanatlı aslan Venedik Cumhuriyeti'ni simgelemektedir. Bir pençesinde tuttuğu ve seyirciye gösterdiği açık kitapta Latince "Barış seninle olsun Markos, benim Evanjelistim" yazmaktadır. Kompozisyonda, aslanın sağ pençesinin altına sorguçlu bir Osmanlı kavuğu yerleştirilmiştir. Aslanın başını çevreleyen halede ise Fransızca "Türkler üzerine galip gelen ve muzaffer olan Venedik Cumhuriyeti” yazmaktadır. Bu üç sembolün çevrelediği savaş sahnesiyse Mora yarımadasında gerçekleşen Kutsal İttifak güçlerinin yardım ettiği Venedik ile Osmanlı arasında geçen savaşın tasviridir. 


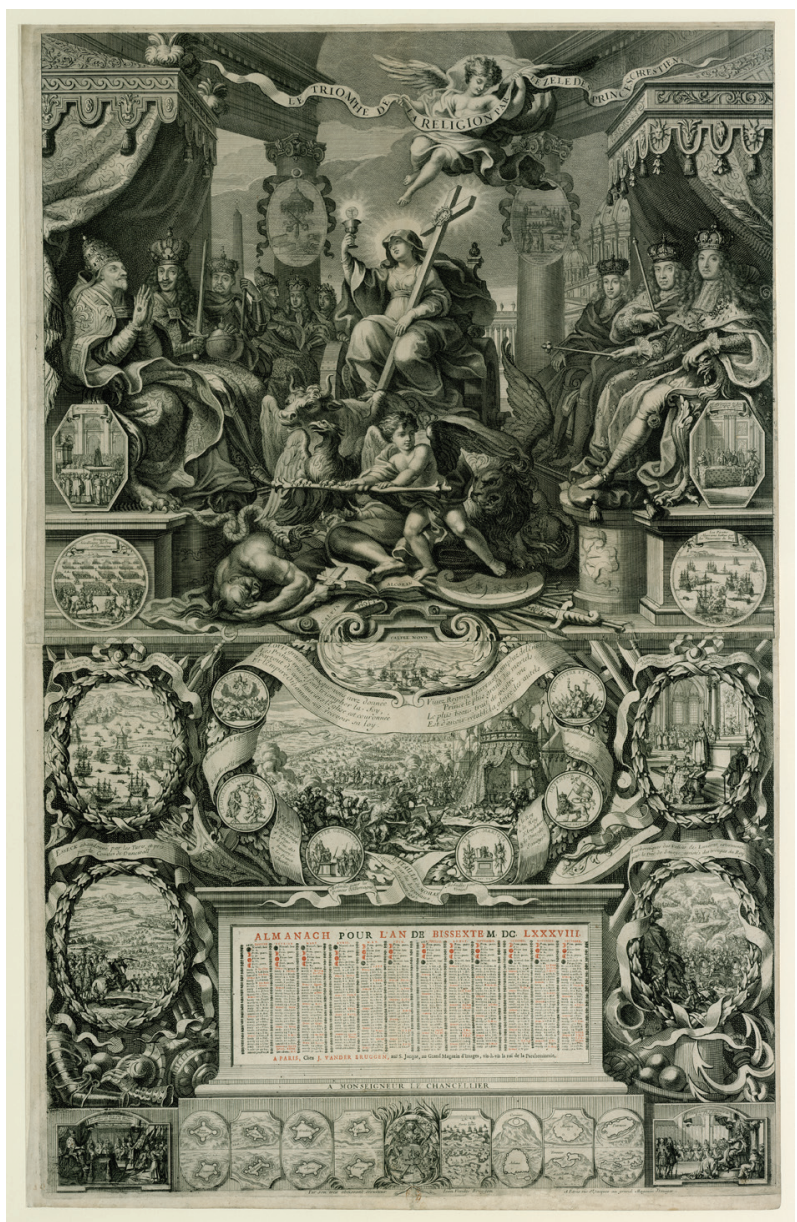

G. 7. Jean van der Bruggen, 1688 Almanağ (Kaynak gallica.bnf.fr / BnF)

1688 yılı için üretilen bir diğer almanak ${ }^{37}$ (G. 7) da yine pek çok sembol ile yoğrulmuş bir anlatıma sahiptir. Her biri sayfanın yarım alanını kaplayan iki bölümden oluşur. Üç ana figür grubundan oluşan bir kompozisyonun arka planında Vatikan'daki San Pietro meydanının silueti verilmiştir. Sütun ve mimari öğeler sahnenin bir iç mekânda geçtiğini gösterir. Sütunların üzerinde kurdeleli elips madalyonlar yer alır, bunlarda papalık arması ve hazırlanan donanma resmedilmiştir. Sağ ve sol taraflarda emperyal perdelerle süslü tahtlar yer alır. Solda, tahtlar üzerinde döneme ait kıyafet ve başlıklarıyla mutlu ve huzurlu yüz ifadeleri ile Papa XI. Innocentius ve Roma-Germen İmparatoru ve farklı unvanlara sahip Avrupalı hükümdarlar oturmaktadır. Numaralandırılan hükümdarların isimleri sayfanın diğer yarısındaki çelengi saran kurdelede verilmiştir. Soldan sağa doğru, Papa ve İmparator Leopold’ü Polonya Kralı, Venedik 
Doçu, Bavyera Dükü ve Prens Charles takip etmektedir. Papa'nın karşısında oturanının kimliğini tasvir üzerinden de tespit edebiliriz. Tahtının oturduğu çıkıntılı platformda bir kurdeleyle çevrelenmiş Güneş tasviri bulunan ve fleur-de-lys amblemiyle bezenmiş kaftanıyla poz veren Fransızların "Güneş Kral”'1 XIV. Louis’dir. Yanında oturanlar sırasıyla İngiltere Kralı ve Savoy Prensi' dir. Önüne bakan Venedik Doçu hariç tüm hükümdarların gözleri seyirciye çevrilmişken Papa'nın bakışı merkezde bulunan gruba yönelmiştir. Grubun üstünde kanatlı bir figür "Hristiyan prenslerin şevk ve gayretiyle kazanılan dinin zaferi” yazılı bir kurdele taşımaktadır ve alttaki figürlere şefkatle bakmaktadır. Bu grubu yorumlamak için öncelikle bazı Hristiyan dini metinlerini ve önde gelenlerini hatırlamak gereklidir. Nitekim dikkat edildiğinde bu almanakta diğer almanakların aksine putto dışında antik Roma öğelerinin ve kıyafetlerinin yer almadığı, ikonografisinin dinî temelli olduğu görülür.

Dört Evanjelist'in başlarından geçtiğine inanılan olaylara kısaca değinmek onları kolayca teşhis edebilmemizi sağlayacaktır. Birinci İncil'in yazarı Matta gümrükçülerin ve finansörlerin koruyucu evliya olarak çevirebileceğimiz patronu sayılır ve ona İncil'i bir meleğin fisıldadığına inanılır. ${ }^{38}$ İkinci İncil'in yazarı Markos'un ise İskenderiye'de şehit edildiğine inanılır. 832 yılında Venedikliler, Markos'un kemiklerini şehirlerine getirip San Marco Bazilikası'nı ona adamışlardır. Böylece Markos, Venedik'in patronu olarak seçilmiştir. Markos'un sembolü olan kanatlı Aslan aynı zamanda bu nedenle Venedik' in de baş armasıdır. ${ }^{39}$ Üçüncü İncil'in yazarı olan Luka'ya Meryem Ana'nın çocuk İsa ile göründüğüne, Luka'nın da onları gerçeğe uygun şekilde resmettiğine inanılır. Boğa ile sembolize edilen Luka, doktor ve ressamların patronu sayılır. ${ }^{40}$ Dördüncü Evanjelist Yuhanna'ya mahşer ve dolayısıyla sözü geçen dört mahlûk tasvirlerinin de yer aldığ1 Apokalips kitabı atfedilir. ${ }^{41}$ İşte bu kitapta geleceğe, kıyamete ve son mahkemeye dair vizyon ve kehanetler yer alır. İçinde birçok başlık yer alan bu kitaptan almanağımızı ilgilendiren "Apokaliptik kadın ve ejder" vizyonudur. Buna göre güneş 1şınlarını giymiş hamile bir kadın -ki başının etrafında on iki yıldız olduğu da rivayet edilir- ay ya da hilal üzerinde görülmüştür. Yedi başlı kırmızı bir ejder, onun yeni doğmuş çocuğunu yemek için kadına saldırmak üzeredir. Erkek olan bebek Tanrı tarafından kurtarılır ve kadın da çöle kaçar. Mikail ve diğer melekler ejderi ve yardımcılarını yenerler. 12. yüzyıldan itibaren bu vizyon Meryem Ana ve İsa olarak yorumlanmış, bazen de kilise kurumunu temsilen tasvirlerde yer almıştır. Dolayısıyla, Apokaliptik kadın tasviri Meryem Ana tasviri olarak da kullanılabilmiştir. Şeytanı temsil eden ejderi -ki yılan olarak da verilir- yenişi Meryem Ana’nın göğe yükselişiyle özdeşleştirilir. Ejder/Yılan ise "kâfirler” ve

38 Sabine Poeschel, Handbuch der Ikonographie: Sakrale und Profane Themen der Bildenden Kunst (Darmstadt: Philipp von Zabern, 2014), 265-266.

39 Poeschel, Handbuch der Ikonographie: Sakrale und Profane Themen der Bildenden Kunst, 263-264.

40 Poeschel, Handbuch der Ikonographie: Sakrale und Profane Themen der Bildenden Kunst, 259-260.

41 Poeschel, Handbuch der Ikonographie: Sakrale und Profane Themen der Bildenden Kunst, 246-248. 
"din düşmanlarını" temsil eder. Bilhassa Katolik Kilisesi, hilal üstündeki Meryem Ana motifini sıklıkla kullanmıştır. ${ }^{42}$ Gravürde elindeki kadeh ve haç ile "Fides" yani "İman" kişileştirmesi olabilecek merkezdeki kadın figürünün birkaç kimlik taşıdığını düşünebiliriz. Diğer gravürler ve Avrupa sanat geleneği düşünüldüğünde, sanatçının şeytanın kovulduğu zamanın sonundaki hayata atıfta bulunabileceğini akılda tutmak gerekir. Tasvirde on iki yıldız yoktur ancak figürü saran güneş ışınları belirgindir. Apokaliptik kadın ikonografisine ait olan hilal açıkça çizilmemiş ise de, dolaylı olarak yerini Müslümanlarla ve Türklerle özdeştirilen hilale bırakmıştır. Çünkü kanatlı Evanjelist sembollerinin altında, ezilmekte olan hilal bezemeli Osmanlı kalkanı, Osmanlı askerleri, silahları ve Kur'an görülür. Kadın figürün bir zafer arabasında Evanjelist sembolleri tarafından taşınması da yine katmanlı bir kimliğe işaret eder. Çünkü bu semboller özellikle araba nedeniyle Vahiy Kitabı'nda geçen dört canlı mahlûku da simgeleyebilir. ${ }^{43} \mathrm{Bu}$ durumda semboller göksel ilahi yardımın yerde tecellisi olarak okunabilir ve Apokaliptik kadın okumasını mümkün kılabilir. Kılıcı kırılan yerde acı içinde yatan bir Osmanlı askerinin üstündeki yılan figürünün kuyruğunu, Papa'nın tahtının aslan pençesi ezmektedir. Yerdeki Kur'an'nın yanında o dönem Katolik Kilisesi tarafindan reddedilen hareketlerin, örneğin Kalvin'in kitapları da bulunmaktadır. ${ }^{44}$ Avrupa sanatında "barbarlığı" simgeleyen yarı çıplak beden, saçsız baş, bıyık ve/veya sakallı yüz de incelenen Fransız gravürlerinde ilk kez burada Osmanlı askerlerinin tasviri için "medeni”" Avrupalılarla tezat oluşturacak şekilde kullanılmıştır.

Fides'nin ya da bir açıdan Apokaliptik kadın olarak da görülebilecek olan figürün taşıdığı haçtaki dikenli çelenk dikkat çeker. Bilindiği üzere Karşı-Reformasyon sırasında Katolik Kilisesi, İsa'nın karşıtları tarafından Çarmıha Gidiş sırasında dikenli çelenk ile alaya alındığı sahneyi İsa'nın kilisenin bölünmesi üzerine duyduğu acıyı ifade etmek için öne çıkarmıştır. ${ }^{45}$ Burada da dikenli çelenkli haç aynı yönde, yani Katoliklik karşısında bulunan Hristiyanlara yapılan güçlü bir eleştiri ve uyarı olarak yorumlanabilir. Figür diğer elinde üstündeki madalyonda çarmıha gerili İsa tasviri olan kadehi tutmaktadır. Sayfanın ikinci yarısında takvim bölümünün üstünde bulunan ana bir tasvir ile sağ ve solunda üst üste ikişer resim yer almaktadır. Her biri zaferi temsil eden çelenk ve kurdeleler ile çevrilidir. Arka planlarında Osmanlılara ait silahlar, mızraklar, oklar, sadaklar, sancaklar, zırhlar, baltalar gözükmektedir. Ana tasvirin çelenginde altı adet küçük madalyon vardır ve üstü Kastelnovo şehrinin tasviri ile taçlandırılmıştır. Altından geçen kurdelede Hristiyan prenslerin birleşerek dinin

42 Poeschel, Handbuch der Ikonographie: Sakrale und Profane Themen der Bildenden Kunst, 204.

43 Poeschel, Handbuch der Ikonographie: Sakrale und Profane Themen der Bildenden Kunst, 104.

44 Kur'an, Avrupa'da 12. ve 13. yüzyıllardan itibaren çevirileri üzerinden İslam dinine ve Peygamberine karşı antipropaganda aracı olarak kullanılmıştır. Ona, "doğru dinin zaferine" vurgu yapan bu gravürlerde yer verilmesi yüzyıllar boyunca süregelen bir söylemin sonucudur. Konu hakkında bkz. Dimmock, "A Human Head to the Neck of a Horse: Hybridity, Monstrosity and Early Christian Conceptions of Muhammad and Islam."

45 Poeschel, Handbuch der Ikonographie: Sakrale und Profane Themen der Bildenden Kunst, 174-175. 
zaferini hazırladıkları, kiliseyi taçlandırdıkları ve böylece Osmanlı İmparatorluğu’na cezasını verdikleri anlatılmaktadır. Bu madalyonlara baktığımızda, Kutsal İttifak'a katılan her bir ülkeye şükran ifade edildiğini görürüz. Soldan başlayarak karşımıza ilkin papalık için olan madalyon çıkar. Latince “Tanrı'nın sağ eli” yazan ve Tanrı'nın kudreti, ihsanı, ilahi müdahale, ilahi adalet manalarında gelebilecek bir başlık altında, bulutların arasında papalık arması resmedilmiştir. Yerde yatan Osmanlı askerlerinin üstünde şimşekler çakmaktadır. Roma-Germen İmparatorluğu madalyonunda Budin'in intikamını alan Leopold ile dirildiği/ayağa kalktığı yazmaktadır. Takip eden madalyonlarda Almanların yardımlarından, Venediklilerin kara ve denizden desteklerinden söz edilirken, İngiltere Krallığ 1 dinin koruyucusu olarak övülmektedir. Fransa Kralı'na ise Hristiyan Kralı olarak seslenilir ve onu temsilen arma ya da portre yerine yukarıda bahsedilen Fides merkezli grubun sadeleştirilerek tasvir edildiği görülmektedir. Yanlardaki tasvirlerde yine savaş sahneleri ve kilisede dua eden İngiltere Kralı gösterilmiştir. En altta da çerçeve niteliğinde yukarıdakine benzer sahneler ve Osmanlı'dan alınan kaleler resmedilmiştir.

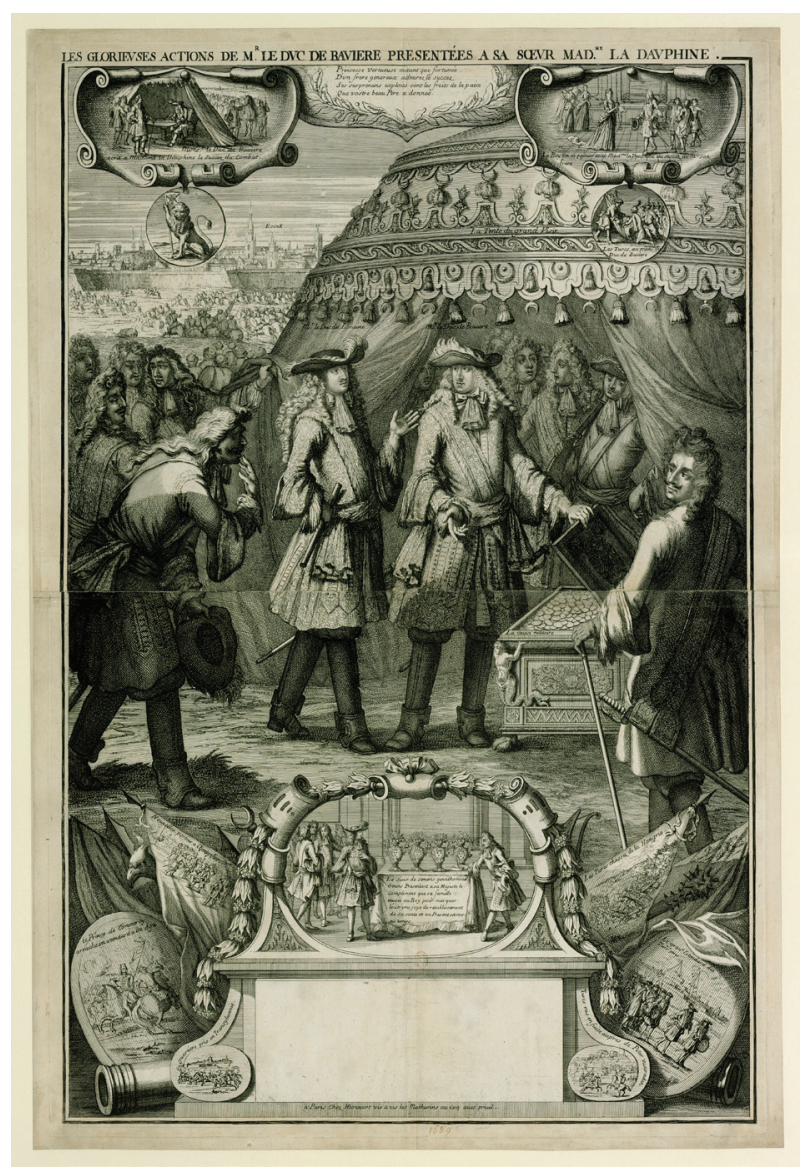

G. 8. Henri Bonnart, 1688 / 1689 Almana $\breve{l}$ (Kaynak gallica.bnf.fr / BnF) 
1689 almanağının ${ }^{46}$ (G. 8) başlığı ise Fransızca "Bavyera Dükü'nün kız kardeşi Dauphine'e sunduğu şanlı gayretleri”dir. Sayfanın sol üstündeki levhada dük kardeşine mektup yazarken görülmekte, sağdaki levhadaysa elinde mektup tutan kardeşi, dükün başarısını kutlamaktadır. Sol levhadan sarkan madalyonda Bavyera arması resmedilirken, sağ levhadan sarkan madalyonda "Türkler Bavyera dükünün ayaklarında" açıklamasıyla bir çadırın önünde Türkler dizlerinin üstüne eğilirken resmedilmiştir. Bavyera armasının olduğu madalyon, resim merkezinin arka planında yer alan Ösek kalesi ve buraya atlar üstünde gelen Osmanlıların üstünde yer alır. Armadaki aslan Osmanlı askerlerine yukarıdan öfkeyle bakmaktadır. Bu iki levhanın arasında ve arka planda yapraklarının içinde Osmanlı'dan alınan kalelerin isimleri yazan, iki dalla çerçevelenen bir şiir yer alır. ${ }^{47} \mathrm{Bu}$ şiir prensesin böylesine başarılı bir prensin kardeşi olması sebebiyle ne kadar şanslı olduğundan bahseder.

Sahnenin çoğunu kaplayan Merzifonlu Kara Mustafa Paşa'nın çadırının önünde Bavyera ve Lorraine dükleri birbirleriyle içi altın dolu Osmanlı askeri hazine sandığı hakkında konuşurken resmedilmiştir. Maiyetindekiler ise çadırı hayretle incelemektedirler. Osmanlı'yı simgeleyen hilallerle ve değerli mücevherlerle bezenmiş çadır, hem hayranlık hem de şaşkınlık uyandırmış gibidir. ${ }^{48}$ Böylece "düşmanın" haşmeti ve zenginliği incelenen gravürlerde ilk kez bu sahnede vurgulanmış olur. Burada da takvim yine Osmanlılara karşı kazanılan zafer notları ve sahneleriyle çevrelenmiştir. Solda ve sağda, bayrak ve kalkan üzerine Türklerin kaçışı, sancaklarının alınışı gibi yazılı açıklamalarla birebir ya da ordu savaş sahneleri, kaçış sahneleri ve Avrupalıların zafer kutlamaları tasvir edilmiştir.

46 Bibliothèque Nationale de France, Recueil. Collection Michel Hennin. Estampes Relatives à l'Histoire de France. Tome 64, Pièce 5602. (Boyutları 83,1 cm x 55,9 cm) (gallica.bnf.fr / BnF)

47 "Princesse vertueuse autant que fortunée / D'un frere genereux admirez le succez / Ses surprenans exploits sont les fruits de la paix / Que vostre beau Pere a donnee."

48 Başta Grothaus olmak üzere yazımızın 18. dipnotundaki referanslar aristokratlar arasında ve yüksek kültürde Türklere karşı duyulan etnografik ilgiden bahsederler. Bu bakımdan sahne, bu "merakı" belirli bir "anda" yakalayabildiği için oldukça ilginçtir. 


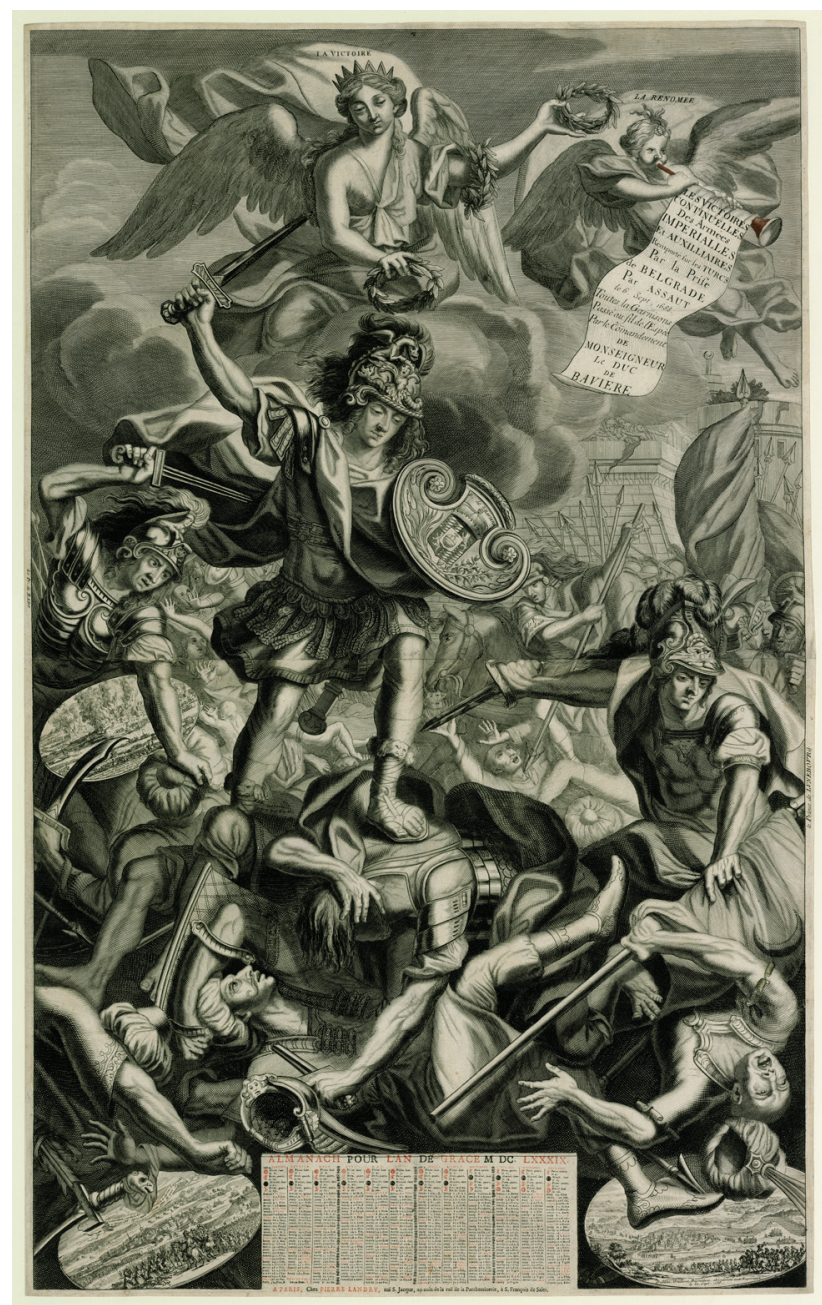

G. 9. Pierre Landry, 1689 Almana $\breve{l}$ (Kaynak gallica.bnf.fr / BnF)

Bir diğer 1689 tarihli almanak ${ }^{49}$ (G. 9) üç adet küçük birer not hükmündeki elips içinde savaş tasvirleri ve takvim kısmı dışında tüm sayfayı kaplayan tek bir ana sahneden oluşur. Bavyera Dükü, Baden Prensi, Saksonya Prensi ve Lüneburg Prensi ana figürlerdir. Bavyera Dükü sayfanın ve kompozisyonun ana hattını oluşturan sol diyagonal eksenin merkezinde konumlanmıştır. Dördü de idealize edilmiş Roma konsülleri şeklinde savaş esnasında betimlenmişlerdir. Aslan yelesini andıran saçlarının üzerinde mitolojik bezemelerle süslü miğferleri vardır. Yalnızca Bavyera Dükü’nün arması görülür. Bavyera Dükü’nün üzerinde kanatl1, taçlı ve togalı, "Zafer" ismi verilen bir kadın figürü yani zafer kişileştirmesi vardır. Beraberinde getirdiği üç adet defne yapraklı çelenkten birini Bavyera Dükü'nün başına takmak üzeredir. Hemen

49 Bibliothèque Nationale de France, Recueil. Collection Michel Hennin. Estampes Relatives à l'Histoire de France. Tome 65, Pièce 5692. (Boyutları 89,8 cm x 55,5 cm) (gallica.bnf.fr / BnF) 
yanında "La renomée" yani "ün/şan/şöhret” yazan kanatlı bir figür yer alır. Saçları sarık şeklinde stilize edilmiş olan bu figür bir borazan üflemektedir. Bu borazandan Bavyera Dükü'nün komutası altında kazanılan süregelen zaferlere ve Belgrad'ın 6 Eylül 1688'de Avrupalı kuvvetlerce alınışına atıf yapılmaktadır. Arka planda Belgrad kalesi görülür. Osmanlılar Alman dükü ve prenslerinin altında ezilmektedirler. Yüzleri dehşet ve korku içindedir. Çoğunun da sırtı yere değmektedir. Silahlarına ve sancaklarına sahip olamamışlardır.

Sol diyagonal eksen izlendiğinde, eksenin başında Bavyera Dükü'nün kılıcının göğe değdiği görülür. Eksenin sonunda, sayfanın sağ ucunda sancağını sıkıca tutan ancak Lüneburg Prensi'nin kendi elinden sancağı almasını engelleyemeyecek şekilde yere düşmüş, kavuğu devrilmiş, gözleri açık bir Osmanlı askeri bulunmaktadır. Figürlerin bu diyagonal eksen üzerinde yukarıdan aşağıya böyle yerleştirilmesi yine yukarıda bahsedilen Kartal-Yılan alegorisine benzer şekilde yorumlanabilir. Eksen yönünden çok benzer bir kompozisyon Roma'da Santa Maria della Concezione Kilisesi'nde bulunan Guido Reni'nin (1575-1642) 1635 yılında yaptığı Mikail Şeytan'a Galip Gelir yağlıboya tablosunda işlenmiştir (G. 10). ${ }^{50}$ Mikail'in rolü Bavyera düküne devredilirken, şeytan yerine de bir Osmanlı askeri resmedilmiştir. İlahi yardıma ve takdire böylece vurgu yapılmıştır. Resmin alt kısmında sağda ve solda bulunan elips şeklinde çerçevelenen sahnelerde sırasıyla Costainitza ve Dubitza şehirlerinin imparatorluk ordularına bırakılışı resmedilmiştir. Costainitza'nın önünde şehri terk etmiş, imparatorluk komutanlarının önünde diz çöken, sarıklarını başlarından çıkarmış, silah ve sancaklarını teslim etmek üzere bekleyen Osmanlılar görülür. Baden Prensi'nin sol kolunun arkasındaki küçük sahnede ise Semendere yanmaktadır. Şehirlerin Osmanlı kimliğini belirtmek için, alemler diğer gravürlerde de olduğu üzere sık sık her türlü yapının üstünde resmedilmiştir. Alman hükümdarların Hristiyan kimlikleriyle değil, Roma varisi olarak resmedilmeleri dolayısıyla Hristiyan sembollerle Osmanlı’ya karşı kazanılan zaferlere dinî bir yorumla yaklaşan diğer almanakların aksine burada Roma11 kültür ve tarih mirasına özellikle vurgu yapıldığı söylenebilir. Kutsal Roma-Germen İmparatorluğu'nun Roma-Germen kimliği de böylece ifade bulmuştur.

50 Albrecht Dürer'in Apokalips'indeki aynı sahnede şeytan görülür ve Türklerle özdeștirme en azından ilk bakışta söz konusu değildir ancak Mikail'in şeytanı etkisiz hâle getirişi, Osmanlılarla olan savaşları anlatan resimlerde ve alegorik kompozisyonlarda özellikle İnebahtı Savaşı'nda sonra sıklıkla kullanılmıştır. Örneğin bkz. Paul, "And the Moon Has Started to Bleed," 79-83. Venedik donanma generali Sebastiano Venier'i 1571 civarında boydan resmeden Jacopo Tintoretto da kompozisyonunun arka planında bu dikey eksen ile ilahi emri vurgulayan Gök-Melek Savaş̧̧-Şeytan / Antichrist / Deccal detayını kullanmışıtır. Paul, Paul, "And the Moon Has Started to Bleed," 79-80. Tintoretto, Venedik'te Michele Bon isimli bir avukatın S. Giuseppe di Castello Kilisesi’ndeki kabrinin altarı için de bu kompozisyonu kullanmıştır. Tintoretto, burada şeytanı belirgin bir şekilde bir Osmanlı/ Türk olarak resmetmiştir: Şeytanın boynuzu bir hilaldir, demirden bir zırh giymektedir ve sakalları vardır. Paul'ün dikkati çektiği gibi, Mikail ve Türk görünümlü Antichrist/Deccal/ Şeytan burada artık bir propaganda amacı taşımaz. Kompozisyonda Michele Bon da bu ana şahit olurken resmedilmiş̧tir dolayısıyla resim meftanın farkındalığına ve iyi bir Hristiyan oluşuna vurgu yapar ki böylece Cennet'e giden yolda önemli bir adım atmış olur. Yani Antichrist/Deccal/Şeytan olarak algılanan Türk'ün kolektif bir hatırlatma yerine burada kişisel bir kurtuluş gayesine dahi hizmet etmesi oldukça ilginç ve kayda değerdir. Paul, "And the Moon Has Started to Bleed," 87-88. 


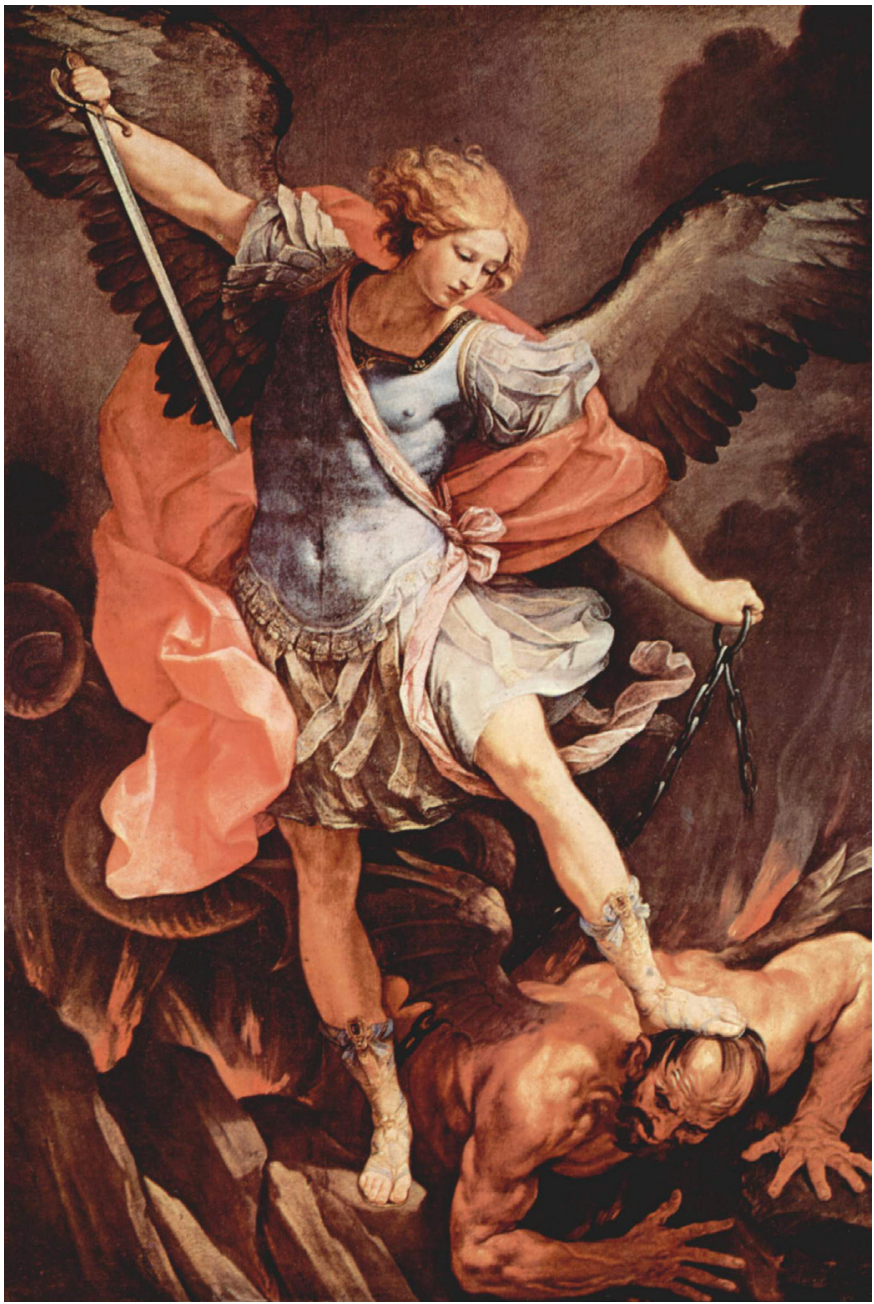

G. 10. Guido Reni, Mikail Şeytan'a Galip Gelir, The Yorck Project (2002) ("10.000

Meisterwerke der Malerei”) https://commons.wikimedia.org/wiki/File:Guido_Reni_031.jpg https://upload.wikimedia.org/wikipedia/commons/6/68/Guido_Reni_031.jpg erişim 1 Äralık 2019

\section{Sonuç}

Avrupa kolektif bilinci ve hafizasını biçimlendiren en önemli aktörlerden olan sanatlı anlatımlarda karşımıza çıkan Osmanlı/Türk tasvirleri ve algısı elbette Türklere karşı izlenen politikaların psikolojik arka planını yansıtmış ve bir anlamda oluşturmuştur. Bu bağlamda, görsel anlatımlara dikkat çekilmeli ve bunlar spesifik sorular 1şığında özenle incelenmelidir. Bu makale Avrupa topraklarında Osmanlı'ya karşı alınan galibiyetlerin seçili gravürler aracılığıyla Fransa'da nasıl karşılandığını sergilemeye çalışmaktadır. Bu yazıda yalnızca kısaca örneklerle hatırlatılsa da zaman ve mekân olarak geniş bir açıdan bakıldığında bu algının yalnızca Fransızlara ait olmayıp 
Kutsal İttifak'ı oluşturan tüm milletlerin en azından "resmi” seviyede Türklere bakışını yansıttığını söyleyebiliriz. Gravürlerde kullanılan ikonografi hem Hristiyanlık öncesi Grek-Roma öğelerinden hem de Hıristiyan öğelerden oluşmuştur. Böylece Kutsal Roma-Germen İmparatorluğu başta olmak üzere Avrupalı devletlerin Roma'nın varisi ve Hristiyanlığın temsilcisi olmalarına vurgu yapılmıştır. Geçmişteki yenilmez düşman artık mağlup hâle gelmiştir. Bu durum Tanrı'dan bir hediye olarak algılandığı gibi Hristiyanlara vadedilen güzel günlerin başlangıcının habercisi sayılmıştır. Avrupalılar tarafından Türkler/Osmanlılar yalnızca Avrupalı hükümdarların değil, Hristiyan dininin ve inandıkları Tanrı'nın düşmanı olarak da görülmüştür. Önceki yüzyıllarda olduğu gibi 17. yüzyılda da bu durumun değişmediği anlaşılmaktadır. Değişen yalnızca belirgin şekilde Türklerin konumudur. Bu durumun sebebi değişmiş olan askeri ve siyasi güç dengesidir. Bahsi geçen Dürer'in eserinde yine bir Hristiyan karşısında "zalim" de olsa bir imparatoru temsilen yerleştirilen Türk figürü, artık 17. yüzyılın sonlarında Avrupa'da kompozisyonlarda gücü tükenmiş ya da oldukça zayıflamış olarak tasvir edilmiştir. ${ }^{51}$ Mekân ve tür yönlerinden daha detaylı ve geniş çalışmalar, Osmanlılara/Türklere 15. yüzyıl ve geç 17. yüzyıl arasında Avrupa Apokalips ikonografilerinde ve/veya ilahi plana dahil edildikleri diğer kompozisyonlarda verilen rolleri daha iyi analiz ve takip etmeyi mümkün kılacaktır.

Hakem Değerlendirmesi: Dış bağımsız.

Çıkar Çatışması: Yazar çıkar çatışması bildirmemiştir.

Finansal Destek: Yazar bu çalışma için finansal destek almadığını beyan etmiştir.

Peer-review: Externally peer-reviewed.

Conflict of Interest: The author has no conflict of interest to declare.

Grant Support: The author declared that this study has received no financial support.

\section{Kaynakça/References}

Bibliothèque Nationale de France, Recueil. Collection Michel Hennin. Estampes Relatives à l'Histoire de France. Tome 62, Pièce 5476. (gallica.bnf.fr / BnF)

Bibliothèque Nationale de France, Recueil. Collection Michel Hennin. Estampes Relatives à l'Histoire de France. Tome 63, Pièce 5547. (gallica.bnf.fr / BnF)

Bibliothèque Nationale de France, Recueil. Collection Michel Hennin. Estampes Relatives à l'Histoire de France. Tome 63, Pièce 5554. (gallica.bnf.fr / BnF)

Bibliothèque Nationale de France, Recueil. Collection Michel Hennin. Estampes Relatives à l'Histoire de France. Tome 64, Pièce 5613. (gallica.bnf.fr / BnF)

Bibliothèque Nationale de France, Recueil. Collection Michel Hennin. Estampes Relatives à l'Histoire de France. Tome 64, Pièce 5602. (gallica.bnf.fr / BnF)

Bibliothèque Nationale de France, Recueil. Collection Michel Hennin. Estampes Relatives à l'Histoire de France. Tome 64, Pièce 5619. (gallica.bnf.fr / BnF)

51 Doktora tezinde Lale Babaoğlu Balkış, Avusturya'daki eserler için de benzer bir sonuca varır. Bkz. Babaoğlu Balkış, “16. - 18. Yüzyıllarda Avusturya Sanatında Türkler,” 76-77. 
Bibliothèque Nationale de France, Recueil. Collection Michel Hennin. Estampes Relatives à l'Histoire de France. Tome 65, Pièce 5692. (gallica.bnf.fr / BnF)

The Yorck Project(2002) (“10.000 Meisterwerke der Malerei”) Erişim 1 Aralık 2019.

https://commons.wikimedia.org/wiki/File:Guido_Reni_031.jpg

https://upload.wikimedia.org/wikipedia/commons/6/68/Guido_Reni_031.jpg

www.khm.at/de/object/3c59dc048e/ Erişim 17 Ocak 2018.

https://www.metmuseum.org/art/collection/search/387568, Erişim 1 Aralık 2019.

Apostolos-Cappadona, Diane. "Beheading/Decapitation." Encyclopedia of Comparative Iconography: Themes Depicted in Works of Art. Ed. Helene E. Roberts. Chicago ve Londra: Fitzroy Dearborn, 1998, 117-124.

Avcıoglu, Nebahat. Turquerie and the Politics of Representation 1728-1876. Londra: Routledge, 2016.

Babaoğlu Balkış, Lale. “16. - 18. Yüzyıllarda Avusturya Sanatında Türkler.” Doktora tezi, İstanbul Üniversitesi, 1994.

Babaoğlu Balkış, Lale. "15. Yüzyıl Sonu, 16. Yüzyıl Başında Avrupa'daki Türk İmajının Albrecht Dürer'in Eserlerine Yansıması.” Gelenek, Kimlik, Bireşim: Kültürel Kesişmeler ve Sanat: Günsel Renda ya Armağan. Ed. Zeynep Yasa Yaman ve Serpil Bağc1. Ankara: Hacettepe Üniversitesi, 2011, 61-68.

Brummett, Palmira. "Turks and Christians: The Iconography of Possession in the Depiction of the Ottoman-Venetian-Habsburg Frontiers 1550-1689." The Religions of the Book: Christian Perceptions 1400-1660. Ed. Matthew Dimmock ve Andrew Hadfield. New York: Palgrave Macmillan, 2008, 110-139.

Campbell Fette, Mirka. "Saving Political Face: The Structure of Power in Hans von Aachen's Allegories on the Long Turkish War." Yüksek Lisans tezi, The University of Texas at Austin, 2011.

Dimmock, Matthew. "A Human Head to the Neck of a Horse: Hybridity, Monstrosity and Early Christian Conceptions of Muhammad and Islam." The Religions of the Book: Christian Perceptions 1400-1600. Ed. Matthew Dimmock ve Andrew Hadfield. New York: Palgrave Macmillan, 2008, 66-88.

Fassl, Johanna. "Punchinello Meets the Turk: Giambattista Tiepolo's Chorus of Oriental Spectators and the Transformation of Cultural Otherness." The Turk and Islam in the Western Eye 1450-1750: Visual Imagery Before Orientalism. Second Edition. Ed. James G. Harper. Farnham: Ashgate, 2013, 95-125.

Fleckner, Uwe, Martin Warnke ve Hendrik Ziegler. Handbuch der Politischen Ikonographie. Münih: C. H. Beck, 2011.

Grothaus, Maximilian. "Eine Untersteirische Turquerie, Ihre Graphischen Vorbilder und Ihre Kulturhistorische Bedeutung." Institut für österreichische Geschichtsforschung 95/3-4 (1987): 271-295.

Grothaus, Maximilian. "Zum Türkenbild in der Adels und Volkskultur der Habsburgmonarchie 1650-1800.” Das Osmanische Reich und Europa 1683-1789: Konflikt, Entspannung und Austausch. Ed. Gernot Heiss ve Grete Klingenstein. Münih: Oldenbourg, 1983, 63-88.

Heppner, Harald. "Der lange Türkenkrieg (1593-1606) -Ein Wendepunkt im Habsburgisch-Osmanischen Gegensatz." Osmanlı Araştırmalarl 2 (1981): 133-146.

İnalcık, Halil. "Siyaset, Ticaret, Kültür Etkileşimi." Osmanlı Uygarlı̆̆ı 2 Cilt. Ed. Halil İnalcık ve Günsel Renda. 2. Bask1. Ankara: Kültür ve Turizm Bakanlığı, 2004, 2: 1049-1089. 
Kut, Naz Defne. "Iconography of a Catholic Victory: The Battle of Lepanto in Italian Painting." Yüksek Lisans Tezi, Koç Üniversitesi, 2018.

Leuschner, Eckhard. "Donau-Toporaphie und Allegorie in der Türkenkriegspropaganda Zwischen Rudolf II. (1552-1612) und Leopold I. (1640-1705)." Barocke Kunst und Kultur im Donauraum: Beiträge zum Internationalen Wissenschaftskongress, 9.-13. April 2013 in Passau und Linz. Ed. Karl Möseneder, Michael Thimann ve Adolf Hofstetter. Petersberg: Imhof, 2014, 1: 113-125. Erişim 13.01.2020. http://archiv.ub.uni-heidelberg.de/artdok/volltexte/2018/5694)

Madar, Heather. "Dürer's Depictions of the Ottoman Turks: A Case of Early Modern Orientalism?." The Turk and Islam in the Western Eye 1450-1750: Visual Imagery Before Orientalism. Second Edition. Ed. James G. Harper. Farnham: Ashgate, 2013, 155-183.

Martin, Meredith ve Gillian Weiss. "Turks on Display during the Reign of Louis XIV." L'Esprit Créateur 53/4 (2013): 98-112.

Messling, Guido. "The Northern View; Albrecht Dürer and the Ottomans." The Sultan's World. The Ottoman Orient in Renaissance Art. Catalogue of the Exhibition at the Centre for Fine Arts, Brussels, 27 February- 31 May 2015, The National Museum in Krakow, 26 June- 27 September 2015. Ed. Robert Born, Michal Dziewulski ve Guido Messling. Ostfildern: Hatje Cantz, 2015, 53-56.

Murphey, Rhoads. Ottoman Warfare 1500-1700. Londra: UCL Press, 1999.

Neumann, Christoph K. ve Petr Štepánek. "Ottoman-Habsburg Relations in the 17th Century." Image of the Turks in the 17th Century Europe, 12 July-9 October 2005 Exhibiton Catalogue. İstanbul: Sakıp Sabancı Müzesi, 2005, 18-35.

Öztuna, Yılmaz. Osmanlı Devleti Tarihi. 2 Cilt. İstanbul: Ötüken Neşriyat, 2004.

Paul, Benjamin, "And the Moon Has Started Bleed: Apocalypticism and Religions Reform in Venetian Art at the Time of the Battle of Lepanto." The Turk and Islam in the Western Eye 1450-1750: Visual Imagery Before Orientalism. Second Edition. Ed. James G. Harper. Farnham: Ashgate, 2013, 67-94.

Pippidi, Andrei. Visions of the Ottoman World in Renaissance Europe. Londra: Hurst, 2012.

Poeschel, Sabine. Handbuch der Ikonographie: Sakrale und Profane Themen der Bildenden Kunst. Darmstadt: Philipp von Zabern, 2014.

Poumarede, Géraud. Haçlı Seferine Son Çă̆rı: Yeniçă̆ Avrupası'nda Osmanlı İmgesi. Çev. İsmet Birkan. İstanbul: İletişim, 2010.

Renda, Günsel. “Avrupa ve Osmanlı: Sanatta Etkileşim.” Osmanlı Uygarlı̆̆ı. 2 Cilt. Ed. Halil İnalcık ve Günsel Renda. 2. Bask1. Ankara: Kültür ve Turizm Bakanlığ1, 2004, 2: 1091-1121.

Schmidt, Heinrich ve Margarethe Schmidt. Die Vergessene Bildersprache Christlicher Kunst: Ein Führer zum Verständnis der Tier-, Engel- und Mariensymbolik. Münih: C. H. Beck, 2007.

Setton, Kenneth M. Venice, Austria, and the Turks in the Seventeenth Century. Philadelphia: American Philosophical Society, 1991.

Silver, Larry. "East is East: Images of the Turkish Nemesis in the Habsburg World." The Turk and Islam in the Western Eye 1450-1750: Visual Imagery Before Orientalism. Second Edition. Ed. James G. Harper. Farnham: Ashgate, 2013, 185-215.

Soykut, Mustafa. Image of the "Turk" in Italy: A History of the "Other" in Early Modern Europe 1453-1683. Berlin: K. Schwarz, 2001. 
Soykut, Mustafa. Papalık ve Venedik Belgelerinde Avrupa'nın Birliği ve Osmanlı Devleti 1453 1683. İstanbul: İstanbul Bilgi Üniversitesi Yayınları, 2007.

Strunck, Christina. "The Barbarous and the Noble Enemy: Pictorial Representations of the Battle of Lepanto." The Turk and Islam in the Western Eye 1450-1750: Visual Imagery Before Orientalism. Second Edition. Ed. James G. Harper. Farnham: Ashgate, 2013, 217-240.

Sturminger, Walter. Bibliographie und Ikonographie der Türkenbelagerungen Wiens 1529 und 1683. Köln: Böhlau, 1955.

Wagner, Georg. "Otuz Y1l Savaşları Döneminde Osmanlı ve Avusturya İmparatorluklarının Politikası." Osmanlı Araştırmaları 2 (1981): 147-166.

Williams, Haydn. Turquerie: An Eighteenth-Century European Fantasy. New York: Thames \& Hudson, 2014. 
